Est Ag 38 (2003) 331-392

\title{
Nietzsche y el cristianismo
}

\section{INTRODUCCIÓN}

Mi pretensión al escribir este trabajo es la de comprender qué entendía Nietzsche por cristianismo. Es decir, cuál es la esencia de eso que llamamos religión cristiana y por qué considera que debe ser tan radicalmente rechazada. Creo que más allá de las posiciones clásicas de Feuerbach haciendo de la religión una proyección de los deseos humanos o de Marx convirtiéndola en garante de la explotación de los pobres, la crítica nietzscheana conserva una actualidad y un atractivo considerable en nuestro tiempo. Nietzsche no deja de sorprender con sus paradojas, con sus retos, con su mirar frente a frente al absurdo y despreciar al ateo burgués y mediocre tanto como al propio creyente. La religión es hedonismo. Creo que aquí reside la sorpresa de su intento. Vosotros los creyentes equivocáis la dirección de vuestros dardos, sois vosotros los verdaderos hedonistas, los que hacéis del placer y el agrado el signo de la verdad. Y efectivamente éste es el argumento: la fe salvạ, luego es verdad. No cabe mayor hedonismo. ¡Qué poca cosa es la fe, que para valer necesita agradar, salvar al hombre! ¡Qué orgullo infantil el nuestro al suponer que la verdad ha de ser agradable y el mundo hecho a nuestra medida!

No puedo dejar de pensar al escribir estas lineas cuánto se acerca Nietzsche a Freud. También el gran analista de la mente humana cree ver en la religión una cuestión de narcisismo, es decir, una cosa de niños. Porque si algo no puede admitir un niño es que la omnipotencia quede en el vacío, sin sujeto titular: omnipotente es él en un principio, sus padres luego y Dios finalmente. Y todo porque, ante la realidad, no podemos estar desprovistos de ayuda y consuelo. Como en Nietzsche, Freud cree que lo real es más bien un ideal regulativo, algo en lo que nunca acabamos de estar. Tan dificil nos resulta, que nos fugamos a nuestros sueños, a nuestros paraísos. Eso es la religión, el sueño de la humanidad, como nuestros sueños son la religión, el mito, de cada cual. Pero sueño que se desconoce como tal. Mentira, dirá Nietzsche que no sabe que lo es. Por eso el nihilismo es nuestro destino inevitable, nace del suicidio del cristianismo cuando éste, al fomentar el espíritu de verdad, acaba 
por descubrirse a sí mismo como mentira. Esta es la tragedia que occidente estará penando por siglos: haber sido cristiano durante tanto tiempo. Acabada la fe, convertida en imposible, lo que ésta nos deja es un mundo feo, pesado, absurdo, sin sentido. Tardaremos en sobreponernos, habrá de nacer un nuevo hombre que nada tenga que ver con el antiguo. Como Zaratustra habremos de perecer en nuestro ocaso.

El recorrido por los diferentes apartados pretende justificar estas afirmaciones. ¿Qué es la realidad para Nietzsche? Devenir y el terror que acompaña al devenir, pero también posibilidades infinitas de creación, mar abierto, ahora más que nunca. ¿Cuál la postura del cristianismo frente a este terror? El idealismo, el más allá, el desdoblamiento de lo real y la reducción de éste a pura apariencia. ¿Por qué? ¿Quién necesita llevar a cabo esta operación metafísica? El hombre débil y cansado, la existencia baja y servil. Este hombre es un resentido, un decadente para quien la vida es un plato demasiado fuerte de digerir. Su odio y sufrimiento se vuelve contra todo lo fuerte hasta nivelarlo por abajo. El sacerdote es su pastor y médico: la vida es dolor porque nace del pecado y la medicina que nos cura, en realidad, la suprime. Como Sócrates, también el creyente ofrece un gallo a Asclepio en el momento de morir por haberle curado de la peor de las enfermedades: la vida.

NOTA: Las siglas utilizadas para citar las obras de Nietzsche por la edición que se reseña en la bibliografía son:

V.P.: Voluntad de poder.

AHZ: Así Habló Zaratustra.

GC: Gaya Ciencia.
MABM: Más Allá del Bien y del Mal. GM: La Genealogia de la Moral. HDH: Humano Demasiado Humano.

\section{EL ATEISMO DE NIETZSCHE}

¿Cómo se hace ateo Nietzsche? ¿Qué tipo de cristianismo conoció y por qué llegó rápidamente a rechazarlo? "Lo que ahora se pronuncia en contra del cristianismo es nuestro gusto, ya no nuestros argumentos" (G.C. $n^{\circ} 132,165$ p.) Es el punto de partida de nuestro estudio. Veamos qué dice Nietzsche de su propio ateismo, por qué llega a considerarlo la expresión de un instinto, una cuestión de buen gusto, como él mismo escribe.

"Dios, inmortalidad del alma, salvación, más allá, simples conceptos a los que no he acordado ninguna atención, con los que no he perdido tiempo ni cuando era niño, ¿quizá no era lo bastante niño? No conozco en absoluto el ateismo como resultado, todavía menos como suceso: en mi caso se trata de un 
instinto"1. Nietzsche nos habla como si su ateismo no fuera el resultado de una evolución intelectual que hace desaparecer una fe antecedente, ni de una evolución espiritual que le libera de antiguas y periclitadas creencias. Su ateismo es visceral, espontáneo, inmediato, un estado de rechazo de las cuestiones religiosas que tiene ya su origen en la juventud.

El conoció un cristianismo fideista separado de toda referencia intelectual. "El cristianismo es esencialmente un asunto del corazón; no sólo si él se incorpora a nosotros, si se convierte en entraña nuestra, el hombre es verdaderamente cristiano. La doctrina cristiana fundamental del cristianismo expresa las verdades profundas del corazón humano; ella es el símbolo de éstas" 2 . En estas condiciones la creencia se vacia de todo contenido y el creyente se pregunta si la fe no es nada más que experiencia de sí mismo. ¿En qué rincón del corazón humano se fragua la fe? Nietzsche comenzó muy pronto a interesarse por la psicología cuando comprende que quizá detrás de la religión sólo hay una búsqueda ferviente de salvación, que sólo la fe (no importa cual) da seguridad y que seguridad es lo que más necesita el ser humano. Intuye la irreductibilidad de lo real a los deseos del ser humano, la desproporción entre el hombre y lo que existe, "algo podría ser verdadero que fuera incluso perjudicial y peligroso en grado supremo; sí, podría ser incluso que perteneciera a la constitución misma de la existencia que se hundiera en el abismo al conocerla enteramente, de tal manera que se podría medir la fuerza de un espíritu por la cantidad de verdad que podría soportar, mejor incluso, en qué medida necesita rebajarla, disimularla, endulzarla, atenuarla, falsificarla" (M.A.B.M.,sección segunda: "El espíritu libre", $n^{\circ} 39,64$ p.). Por eso no quiere cegarse con la falsa claridad de las evidencias lógicas, morales y religiosas (conocer es tranquilizarse) y se propone levar anclas, soltar las amarras. El cristianismo que conoció le condujo a no ver en la religión más que ese tipo de búsqueda, esta caida en la ilusión de quien no puede sobrevivir sino a costa del autoengaño. Efectivamente lo religioso asegura, pero no es verdad.

La ruptura inaugura un movimiento positivo, la entrada en una aventura personal que se impone como una tarea desde el momento en que el cristianismo se muestra como una interpretación general de la existencia del hombre que extravia, banaliza, uniformiza la vida. No hay una receta que pueda salvar a todo hombre. Cada uno debe ser médico de sí mismo. Estamos necesitados de un sano egoismo que nos obligue a tomar en serio la propia vida en lugar de perdernos en la adhesión a una teoría general. La felicidad se encuentra en la búsqueda jamás acabada, paciente, dolorosa de la misión

1. VALADIER, P., Nietzsche l'athée de rigueur, p. 17. Es una cita de Ecce Homo.

2. VALADIER, P., Ibidem, p. 22. 
de cada cual. Para conseguirlo se impone salir de las facilidades de los hábitos fortalecidos por las tradiciones seculares. Pero "cómo ignorar que se prefiere siempre un puñado de certezas a un montón de bellas posibilidades" (M.A.B.M. sección primera: "De los prejuicios de los filósofos" $n^{\circ} 10,29$ p.). Toda la vida de Nietzsche puede ser leida como el intento de abandonar la falsa seguridad del hábito y entrar en el descubrimiento y la acogida de nuevas posibilidades. El hombre está en perpetuo cambio, somos viajeros continuamente transformados por las peripecias del propio viaje. "La serpiente que no puede cambiar de piel muere. Igualmente los espíritus a los que se impide cambiar de opinión; cesan de ser espíritu"3. Por ello forma parte de la naturaleza humana, ser espiritual, el ser acto de metamorfosis, no parada o reposo fatigado sino acto de engendramiento de sí. En el peligro está la salvación y no en la seguridad de la fe. Es el riesgo el que nos salva, el de encontrar cada uno su propio camino. Nuestra misión es un tirano íntimo que se venga cada vez que queremos eludirlo.

Al abandonar la fe Nietzsche comienza su propio viaje, su propia aventura, su propio camino: "Este es mi camino, ¿dónde está el vuestro?, así respondía yo a quienes me preguntaban por el camino. ¡El camino no existe!" ( $A H Z$ Del espíritu de la pesadez, 272 p.). El camino no existe: cada uno es poeta, artista y demiurgo de su existencia. Aventura peligrosa porque supone salirse de las sendas trilladas y encaminarse hacia una verdad que es abismal ("Yo valoro a los hombres por la cantidad de verdad que pueden asumir"). Vivir sin sentido sólo es posible para voluntades fuertes e incluso éstas necesitan del autoengaño, de la ilusión del artista que baila al borde del abismo. Este arte hace posible la vida, el arte como error útil, verdad pragmática que puede ser sobrepasada. Pero existe también una patología de la ilusión, un exceso en el engaño, una degeneración del pragmatismo vital útil. Este puede degradarse para ponerse al servicio del hombre débil, del que necesita de un "plus" de seguridad. Se trata del idealismo utilitarista, esencia de la religión, que ya no está al servicio de la vida.

La religión se alimenta de la calumnia de lo sensible y de la fábula del más allá donde habita el ser inmutable: "la creencia en el ser muestra no ser más que una consecuencia: el auténtico primun mobile es la no-creencia en el devenir, la desconfianza respecto al devenir, la depreciación de todo devenir" (V.P., $n^{\circ} 577,327$ p.) es decir, la imposibilidad para cierto tipo de hombres de soportar la vida. La religión es por ello la ideología de aquellos para quienes la vida es desmesurada, una tarea excesiva. El cristianismo es la religión de los agobiados, del gran cansacio de vivir.

3. VALADIER. Ibidem, p. 28. Es una cita de "Aurora". 
Resumiendo: desde joven juzga la religión como un obstáculo en la vida del hombre. Obstáculo porque ella no es sino una búsqueda patológica de seguridad, la expresión de una auténtica fobia, del miedo a la aventura de la vida. No hay pretiles para nuestro caminar y búscarlos es encerrarse en caminos trillados que no son los nuestros. El cristianismo no dice nada del mundo, dice del sujeto que habita el mundo y dice que éste está abrumado por el peso de la vida, es nada más que la expresión de un deseo, el cumplimiento de una función securizante.

\section{LA FE SALVA, LUEGO ELLA MIENTE}

Vamos a comenzar aclarando la posición de Nietzsche respecto de la crítica más habitual al cristianismo: la que tiene su origen en el pensamiento de Feuerbach. Nietzsche no es un humanista y no pretende por tanto substituir a Dios por el Hombre. Su óptica es muy diferente. Este apartado debe permitirnos comprender que para Nietzsche, el cristianismo es una forma oculta de hedonismo, un intento de tranquilizarnos proponiendo una connivencia oculta entre la realidad y nuestros deseos. Dios sería el garante de dicho acuerdo. Intento compartido también por el humanismo postcristiano. No habría por ello una diferencia cualitativa entre Feuerbach y el cristianismo.

Efectivamente el ateismo de Nietzsche no tiene sus raices en la filosofía feuerbachiana. Se le malinterpreta profundamente cuando se hace de él un crítico posthegeliano de la religión. No se trata de recuperar, gracias al ateismo, los atributos alienados en Dios por el hombre. En la concepción feuerbachiana la divinidad es el resultado de la expropiación de lo mejor de nosotros, antropología camuflada que sería necesario recuperar como tal para situar al hombre en el centro del universo. Pero Nietzsche no es un defensor del Prometeo que encuentra en Dios un obstáculo para el ejercicio de un auténtico humanismo. Para el prometeismo moderno, nacido de la ilustración, la esencia divina no es más que la proyección ilusoria y fantástica de la esencia humana, el hombre inconsciente de sí mismo, por eso el ateismo sería una forma de humanismo por el que retomamos en nosotros mismos los atributos divinos falsamente hipostasiados.

Pero Nietzsche no es un humanista. El representa una opción contra la cultura y la ciencia. "Para quien crea que la historia humana es la crónica de nuestra liberación paulatina de las tinieblas de la animalidad y nuestro ascenso, lento pero constante, hacia formas cada vez más altas de convivencia y conocimiento; para quien crea que la razón científica empírico-matemática, objetiva y desinteresada, es el más refinado logro de la civilización; para quien 
piense que los valores morales vigentes, el igualitarismo cristiano consolidado por la ilustració democrática, la sublimación de las pasiones en pro de logros más elevados, como cimiento de toda sociedad humana... para quien piense así, Nietzsche es la peor regresión imaginable" ${ }^{4}$. El vio en este humanismo un nuevo avatar de la loca pretensión humana de medir las cosas a partir de sí. El tema de la muerte de Dios no significa que, al borrar a Dios, el hombre puede tomar su lugar con el propósito deliberado de convertirse en el centro de toda la realidad que no es él mismo. Justamente lo contrario: la muerte de Dios representa la imposibilidad para el hombre de asimilarse lo real convirtiéndolo en producto de una voluntad divina. Desdivinizar el mundo es también deshumanizarlo, volverlo a percibir como frío e indiferente, sordo a las demandas del hombre. Por eso Dios ha muerto, pero muchos no saben qué hacer con su muerte: "El nihilismo está ante la puerta: ¿Dónde nos llega éste, el más inquietante de todos los huéspedes?" (V.P., $n^{\circ} 5,31$ p.).

La pretensión humanista muestra la esencia de la filosofía occidental que Nietzsche identifica con la metafísica. El humanismo ilustrado es su último heredero. ¿En qué consiste esta esencia? En algo que podríamos llamar hedonismo idealista. Se trata de la pretensión metafísica de que el ser colma las aspiraciones morales del hombre. Una providencia divina lo pondría de acuerdo, a priori, con nuestras necesidades. A causa de ello el ser es bueno, veraz, ajeno al dolor, al cambio o a la lucha. El bien es su esencia. Así lo propone Platón en su filosofía cuyo núcleo central es una agatología. Todo cuanto existe manifiesta y refleja el bien. De esta manera el ser verdadero está absolutamente substraido al devenir. El devenir que es caducidad y finitud, manifestación de la entropía que degrada la existencia. Sin embargo, más allá de las apariencias sometidas a perpetuo cambio (Heráclito) está el mundo inteligible, un ámbito, el reino del ser, libre de todo devenir. El ser es la antítesis del cambio y de esta forma la cultura occidental aparece como cultura del remedio. Necesitamos salvarnos del devenir, del fluctuar entre dos nadas, aquella de la que venimos y aquella a la que retornamos. El ser eterno e inmutable nos libra de la entropía, en él se proyectan nuestras preferencias subjetivas. Todos nuestros deseos y exigencias morales se camuflan bajo este concepto. Enmascarados allí y como adquiriendo un tinte de neutralidad que les hace pasar por lógicos y aceptables. Para los filósofos lo que es, no deviene, lo que deviene no es. Por lo tanto nuestros deseos más profundos coinciden con la realidad. En esto consiste el hedonismo: el acuerdo entre lo que deseamos y el fondo profundo de las cosas, como si el mundo estuviera hecho para nos- 
otros, "listo para ser usado", a nuestra disposición. La materialización del hedonismo es el sentido último de la filosofía: "La ingenuidad estribaba simplemente en tomar la idiosincrasia antropocéntrica por la medida de las cosas, como norma de lo real y de lo irreal; o lo que es lo mismo: en hacer absoluta una cosa condicionada. De repente el mundo se divide en un mundo-verdad y un mundo-apariencia... El proyecto consistía en engañarse de una manera útil, en medio de fórmulas y de signos por medio de los cuales se pudiese reducir la multiplicidad turbadora a un esquema útil y manejable" (V.P., $n^{\circ}$ 576, 325 p.).

Que el hedonismo constituye la esencia de la metafísica lo prueba la elucidación del significado del concepto de verdad. Algo es verdadero si el juicio correspondiente procura satisfacción al alma humana. Beatitudo index veri. La verdad es la verdad porque ella vuelve al hombre mejor. El metafísico no hace sino seguir la opinión popular, porque "siempre los hombres han creido que lo que parecía ser más precioso era lo que había de más verdadero, de más real"5. Deseamos a cualquier precio que la verdad sea útil, que ayude, asegure, consuele. De este modo el cristianismo es verdadero porque es necesario, porque ayuda y alienta. Existe una providencia divina buena y verdadera que garantiza que todo lo que es necesario para nosotros sea igualmente verdadero. Para muchos la vida sería insoportable si no hubiera Dios, pero es una presunción creer que deben darse las condiciones necesarias para nuestra conservación.

Como consecuencia la verdad se deja reconocer en el contentamiento subjetivo que acompaña a su aprehensión por el entendimiento humano. La verdad es eminentemente tranquilizadora. Por eso su primer atributo es la identidad substancial que garantiza su posesión permanente. La verdad es clara y delimitable, exenta de todo error, de toda relación, de toda ambigüedad. Luminosa como el sol, nos arrastra fuera de la oscuridad y la frialdad de la cueva en la que el error nos atenaza. Su segundo predicado es la permanencia. Sólo así se garantiza una posesión definitiva más allá de los desencantos del mundo sensible. Fuera del tiempo, la verdad es definitivamente apropiable. Nietzsche vio en la aspiración a la verdad transcendente la máscara de una simple voluntad de seguridad: "La felicidad no puede sentirse garantizada más que por lo que es: el cambio y la felicidad se excluyen uno a otro. Por consiguiente, la ambición más alta es conseguir la identifición con el ser. Esta es la fórmula que conduce al camino de la mayor felicidad" (V.P., $n^{\circ}$ 577, 327 p.). Todos los aspectos extraños son eliminados para conseguir habitar en un mundo familiar. Los predicados de identidad y permanencia traducen el

5. GRENIER,J. Le problème de la vérité dans la philosophie de Nietzsche, p. 61. Cita "El viajero y su sombra". 
miedo del hombre a no controlar el deslizamiento del tiempo y ello hasta el punto de segregar un mundo-verdad en el que no existe el devenir. Nietzsche quiere substraer al hombre de esta actitud estéril de venganza: "Es muy importante suprimir el mundo-verdad. El es quien disminuye el valor del mundo que formamos y el que origina dudas contra él: el mundo-verdad ha sido hasta hoy el más grave atentado contra la vida" (V.P., $n^{\circ} 575,324$ p.).

El tercer predicado de lo verdadero concierne a la inteligibilidad, a la racionalidad que incluye la claridad, la distinción, la unidad, la coherencia lógica. El ser es definido como logos, como permeable a las categorías de la razón humana, que el optimismo científico utiliza para instaurar el reino planetario de la técnica. La fe en el poder de la lógica es una consecuencia directa de la fe metafísica en la identidad del ser y del ideal. Pero esta afirmación de la logicidad de la realidad no conserva sentido sino por su relación con la ficción metafísica del ser, como permanencia sustancial y norma absoluta de toda inteligibilidad: "Para poder pensar y razonar es obligado admitir la existencia del ser. La lógica no utiliza sino fórmulas correspondientes a cosas estables. Por eso la citada admisión no tendría fuerza de demostración respecto de la realidad; lo que "es" forma parte de nuestra óptica... Un mundo en devenir no se podrían inteligir en el sentido estricto de la palabra: solamente en cuanto la inteligencia que comprende y que conoce encuentra un mundo previamente creado por un procedimieto grosero, constituido de meras apariencias; sólo en tanto este género de apariencias remansa la vida, hay algo como conocimiento: es decir, un mensurar los antiguos errores con otros" (V.P., $n^{\circ} 514,292$ p.). El ser es una creación de la gramática que petrifica el devenir, lo remansa para poderlo explicar, es decir, para poder tranquilizarse.

Pero el garante último de la armonía entre ser y deseo es Dios. El es la personificación de la armonía preestablecida que la metafísica afirma existir entre el ser y la vocación ética del hombre. Asume por tanto las funciones de garante ontológico supremo, primer motor y principio de la legalidad del cosmos. En el orden práctico es el guardian de los valores supremos, el juez y remunerador. Gracias a él todo está organizado en función del bien y de la promoción moral del hombre. "Esta confianza absurda en el curso de las cosas, en la vida, en el instinto vital, esta honrada resignación que cree suficiente que cualquiera cumpla con su obligación para que todo vaya bien, todo esto, no tiene sentido mientras no aceptamos una dirección de las cosas sub specie boni" (V.P, $n^{\circ} 242,156$ p.). ¿Qué puede persuadirnos de la inteligibilidad de lo real, de la dignidad de la razón y del carácter sagrado de la existencia, sino la fe en la infinita solicitud del creador respecto de sus criaturas?

La fe teológica es indispensable para sostener el edificio del idealismo metafísico. Con ello se opera una anexión de lo sagrado a la fábula metafísi- 
ca de un mundo armonioso lo que supone un alarmante deterioro de lo sagrado mismo, una contaminación de la idea de Dios por los temas del bien y del mal: "Yo no creería más que en un dios que supiese bailar"(A.H.Z. 70 p.), afirma Zaratustra, un dios más allá del bien y del mal, no culpabilizador ni condenador de la existencia, a causa del caos y dolor. Este dios juega el juego del azar inocente, un dios que ama la vida tal cual es, sin reducirla al deseo humano. Pero, frente a la manera griega de entender lo sagrado, el cristianismo representa la moralización de la divinidad, la asimilación de lo sagrado a lo moral y con ello la condena de la vida. Con la fe cristiana la percepción de la existencia como sufrimiento alcanza su cima y un determinado tipo humano adquiere el predominio: "Si encuentran un enfermo, o un anciano, o un cadáver, en seguida dicen: la vida está refutada. Pero sólo están refutados ellos, y sus ojos, que no ven más que un solo rostro en la existencia"(A.H.Z., De los predicadores de la muerte, $77 p$.).

Con el tiempo la religión ha perdido fuerza pero no la mentalidad que ella ha promovido. La ciencia es para Nietzsche heredera de la cosmovisión metafísica y religiosa en una época en la que ya no es posible seguir creyendo en las fábulas de la religión, pero donde las actitudes de fondo continuan siendo las mismas: la ciencia no supone ninguna novedad al respecto. Reencontramos el hedonismo bajo la máscara seductora del optimismo lógico, bajo la creencia en el valor redentor del saber. El heredero del optimismo epistemológico es la ciencia. Ella cree en la primacia absoluta de la lógica. Esta sobre-estimación está en las antípodas del pesimismo de la fuerza que se expresaba en la tragedia griega y que la victoria del socratismo reemplazó por un racionalismo superficial e ingenuo. El verdadero antagonismo no se da entre religión y ciencia como pretenden los positivistas, sino entre una concepción trágica y una concepción teórica del mundo. No es pues la ciencia el verdadero enemigo de la religión. Más bien ella prolonga la mismas actitudes de fondo. Por ello la pregunta básica es: ¿se desarrolla la relación con el mundo al modo de una relación sensata y tranquilizadora o al modo de una relación insensata y trágica? ¿Del lado de quién está la razón, de los confiados o de los desconfiados? Nietzsche verá en el predominio del optimismo, de lo racional, del utilitarismo teórico, un síntoma de fuerza declinante, de cobardía, de la necesidad de acuerdo entre mundo y deseos. La modernidad ha apagado el sol de la divinidad cristiana pero ha encendido otros en su lugar porque no es capaz de vivir en la oscuridad.

La ciencia reposa sobre una creencia: la fe metafísica en la dignidad absoluta de la verdad. Esta voluntad de verdad a cualquier precio recubre la simple aspiración a un mundo estable, conforme con el esquema del ser, con los predicados que, en la tradición metafísica, pertenecen a la definición de lo 
absoluto. Es el miedo y el instinto de seguridad los que inspiran el proyecto científico como lo hacen con el metafísico y religioso:"La ciencia moderna tiene por fin: el menor dolor posible, la mayor vida posible, por consiguiente una especie de felicidad eterna, en verdad bastante modesta en comparación con las promesas de las religiones" (H.D.H. parte I, $n^{\circ} 128,119$ p.). En la ciencia se expresa la misma necesidad que empuja al hombre a crear la fábula del mundo inteligible del que estaría excluido el dolor, la contradicción, la lucha, la ambigüedad, el devenir. Oculta una opción racionalista y utilitarista sobre el sentido último del ser. Ella hace del entendimiento humano la medida de las cosas.

Los científicos con su pretensión de neutralidad y objetividad sólo alcanzan una realidad abstracta. Eliminan de la observación científica la pasión, lo afectivo, las inclinaciones. Se trata de la reaparición camuflada de la condena de lo sensible tal como está en la religión y la filosofía occidental. Detrás se oculta una negación de la vida en favor del intelectualismo, de la abstracción estéril. Reencontramos la vieja oposición del socratismo y del pesimismo trágico, el conflicto de la lógica y de la exhuberancia vital.

Consecuentemente Nietzsche critica con dureza ("Primera consideración Intempestiva") la ideología cientista del progreso de D.F. Strauss. Ve en ella la sustitución de la antigua fe cristiana por una nueva. También la ciencia busca un universo tranquilizador donde la verdad sea fácilmente alcanzable. El dominio racional por el esfuerzo científico anhela el cielo en este mundo. Este es el ideal no científico que alienta toda ciencia. Ella es voluntad de un cielo sobre la tierra. Así la infinitud del progreso científico imita la eternidad de la fe religiosa. Es la historia del hombre que busca tranquilizarse y que por ello huye de toda relación trágica con el universo. Quererse dar un mundo a nuestra imagen delata una voluntad que busca precaverse contra toda perdición. Sea fe religiosa o ciencia, encontramos lo mismo: rechazo a ver lo que hay, a comprender que no existe relación entre lo que el hombre se imagina del mundo y el mundo mismo. Algo que Nietzsche aceptó gracias a Schopenhauer. La ciencia rechaza el dogmatismo religioso pero presupone la misma actitud que hace posible la fe. Romper con un credo no es romper con la voluntad que ha creido en ese credo. No se ha transmutado la forma de relacionarse con el mundo. El paraíso de la ciencia es el cielo, lugar de un pretendido aplacamiento total de los deseos humanos, aunque sea un cielo inmanente, pero es el mismo sueño hedonista de la religión: nada ha cambiado respecto del cristianismo.

El criterio de verdad es el placer, experiencia que resulta del acuerdo entre el yo y el fondo de las cosas, acuerdo que no es solamente el objeto de una contemplación fría, sino de una emoción poderosa que invade a toda la 
persona. El contentamiento subjetivo es para el yo una confirmación. Pero Nietzsche advierte que nunca puede ser un argumento para demostrar nada: "Siempre se han tomado los buenos sentimientos por argumentos, un pecho hinchado de entusiasmo..." En "Humano, demasiado humano" se encuentra una dura crítica de la creencia y confusión funesta entre el grado de convicción y la probabilidad de una verdad: "La creencia fuerte no prueba no prueba mas que su fuerza no la verdad de lo que se cree". El deseo de que lo que nos hace felices sea también verdad nos hace tomar malas razones por buenas. El placer inherente a una convicción no constituye una prueba en su favor, es más bien un argumento en contra de la doctrina correspondiente: "Si la fe no volviera feliz, no habría fe: que poco valor debe entonces tener" (H.D.H parte $I, n^{\circ} 120,116$ p.) De este modo la sangre de los mártires es el peor testimonio de la verdad.

Entre conocimiento y creencia, saber y convicción hay un antagonismo mortal. Las convicciones son enemigos de la verdad, más peligrosas que las mentiras. Allí donde la inclinación a dar la adhesión es más fuerte, allí hay que redoblar la vigilancia y poner los puntos de interrogación. Nietzsche quiere dinamitar la famosa argumentación "la fe salva, entonces es verdadera" que maquilla bajo apariencia de argumento un hedonismo implícito. Nietzsche lo vuelve del contrario: "La fe salva, entonces miente". Se trata de poner en duda la piedra angular de la metafísica, el postulado según el cual el criterio de la verdad reside en la satisfacción subjetiva que nos procura su posesión, la garantía de que el descubrimiento de la verdad va necesariamente unido al progreso moral del hombre. La confianza como actitud ingenua es destruida. El criterio de placer responde a una ilusión enorme: la ficción de un mundo que corresponde a nuestros deseos. "La prueba de placer es una prueba de placer, nada más; ¿Cómo se podrían saber que los juicios verdaderos causan mayor placer que juicios falsos, y que, conforme a una armonía preestablecida, implicarían necesariamente detrás de ellos sensaciones de placer? La experiencia de todos los espíritus serios muestra lo contrario. Ha habido que conquistar por la lucha cada parcela de verdad, se ha tenido que sacrificar todo lo que nos tienta, todo lo que amaba nuestro amor y nuestra confianza en la vida. Hay que tener para ello grandeza de alma: el servicio de la verdad es el más duro servicio" 6.

Schopenhauer hizo posible que Nietzsche asumiera otro tipo de planteamiento. Aceptar el ocaso de la interpretación cristiana es aceptar ver la existencia tal como es: no divina, carente de sentido. Emerge con Schopenhauer la

6. GRENIER,J, J. o.c., p. 97. Es una cita de "El Anticristo". 
verdadera pregunta que el cristianismo no permitía aflorar: la cuestión del valor de la vida. La existencia es restituida a su dureza y aspereza. Pero Schopenhauer es un melancólico y con ello delata su dependencia sutil del cristianismo: como el mundo ya no está ordenado a la salvación del hombre, este mundo no puede ser sino horrible. Es la concepción de la vida como culpa: como si Dios fuera ahora el pecador y el hombre su salvador. Hay en el juicio despectivo sobre el mundo que lanza Schopenhauer una nostalgia de lo religioso: querríamos que la vida tuviera sentido pero no lo tiene y nos sentimos despechados. Por eso la voluntad es en Schopenhauer deseo insatisfecho, tendencia dolorosa, búsqueda sin fin. La única salvación posible consiste en la negación de esta voluntad y el rechazo del mundo. Tras la supravaloración del individuo en el cristianismo se pasa a la infravaloración motivada por la decepción. La pérdida de sentido hace aparecer como evidencia la vanidad de la existencia. Se desprecia el mundo por no responder a lo esperado de él. Schopenhauer acaba midiendo la vida a través de una necesidad humana, como ya hiciera la ciencia y el cristianismo, por eso es un desencantado, un nihilista: "El filósofo nihilista está convencido de que todo acontecimiento no tiene sentido, de que todo sucede en vano, y también de que no debería existir nada sin sentido ni en vano. Pero ¿por qué este no debería? ¿De dónde se toma este sentido, esta medida? El nihilista quiere decir, en el fondo, que la consideración de una tal existencia vacía e inútil, no es satisfactoria para un filósofo, le produce tristeza y desesperación... Nos hace llegar a esta absurda valoración: el carácter de la existencia debería satisfacer al filósofo para que ésta pueda mantenerse con pleno derecho..." (V.P., $n^{\circ} 36,47 p$.).

Para acabar este apartado. La duda que Nietzsche plantea se resume en esta pregunta: ¿En nombre de qué deberá el mundo responder a los deseos y a las necesidades humanas? Existe una total inadecuación entre existencia y necesidad del hombre. La toma de conciencia de esta inadecuación supone el comienzo de la emancipación respecto de la fe cristiana y de toda forma de humanismo. El cristianismo hace de la vida un espacio de calma y armonía donde todo riesgo y peligro es borrado. Pero con ello es la vida misma la que es eliminada. Sólo la ruptura con este hedonismo enmascarado permitirá el acceso a una nueva manera de ver la existencia que no la niegue ni por el recurso al más allá ni por el desprecio pesimista y la fuga de tipo budista que tentó a Schopenhauer, ni finalmente por el paraiso tecnológico que promete la ciencia. 


\section{EL "MAS ALLÁ" COMO REMEDIO AL DEVENIR}

¿Por qué el mundo se niega a plegarse a nuestros deseos? ¿Qué hace de él un ámbito inhóspito en el que tantas veces nos sentimos a disgusto? En definitiva ¿de qué necesitamos ser salvados? La respuesta está en el devenir. El mundo es devenir, tiempo, finitud, aquello que Aristóteles conceptualizó como admirable pero también terrible. Nietzsche ve en la religión y en la metafísica occidental un intento de provocar la parálisis, de detener el cambio para poder habitar un mundo hecho a nuestra medida. Veámoslo.

El concepto nietzscheano del devenir procede sin duda de Heráclito y es concebido como la trama que condena a morir todo cuanto vive, el fundamento del carácter terrible de la verdad sobre las cosas. Ya los griegos captaron desde el principio su carácter admirable y terrorífico. En virtud del devenir, empezar a existir y dejar de existir es lo mismo.

En sus primeras obras Nietzsche habla de una unidad primordial indeterminada de la que nace lo finito y determinado. Este nacimiento lleva aparejado el dolor porque implica una transgresión. El proceso de desaparición de lo finito y la reposición de la unidad originaria en su unidad excluyente constituye una expiación. El devenir pierde su inocencia y se torna idéntico a la originación de la culpa: llegar a ser es llegar a ser culpable, comenzar a existir es comenzar a penar. Schopenhauer respondía con la negación de la voluntad de existir. El pesimismo es la reacción ante la fragilidad de la existencia." El error fundamental de la voluntad en Schopenhauer es típico: disminución del valor de la voluntad hasta el desconocimiento. De la misma forma, el odio contra el querer; intento de querer ver en el ya-no-querer, en el ser sujeto sin finalidad ni intencionalidad algo superior, incluso lo supremo en sí, la entidad. Gran síntoma de cansancio o de la debilidad de la voluntad" (V.P., $n^{o} 84$, 73p.).

Este concepto del devenir es compartido por toda la filosofía occidental. Supone la ontologización del concepto de culpabilidad. El mundo es culpable del dolor que nos infringe, de la ausencia de sentido. En consecuencia vivimos resentidos, profundamente heridos. Por eso necesitamos el consuelo de un dios.

Fenomenológicamente el devenir es colección de instantes, momentos fugaces entre dos nadas. El instante es el ámbito único de la existencia, único remanso de mínima estabilidad y permanencia, allí donde todo cuanto existe deja de existir. El fluir que constituye el devenir implica que cada instante se alimenta de la muerte del anterior y expía su culpa frente a él sometiéndose al dolor de verse sustituido por el que le sigue. La memoria del paso del tiempo convierte todo goce en sufrimiento, condena el presente a la insignifican- 
cia. Nada sino el recuerdo confiere unidad a la multiplicidad instantánea, nada sino el dolor y el espanto de existir se conserva idéntico por encima del cambio. El devenir se alimenta de cadáveres, es el tiempo que come la vida. Cada instante devora al anterior como Saturno a sus hijos. La movilidad del devenir se caracteriza como apetencia oral, oralidad insaciable; el tiempo se ve empujado por su apetito de futuro, arruinando a los individuos, haciéndolos emerger y hundirse, surgir y desaparecer. El individuo es instantáneo, fugaz... por eso tiempo e insatisfacción son lo mismo.

Entonces el pensamiento sólo se ejerce para tranquilizarse: acondicionar un espacio de reposo para el hombre, preservarle del horror primordial. Las únicas identidades, remansos de inteligibilidad, se las debemos al lenguaje, a su red de conceptos estables. Construimos sobre el devenir y consideramos lo construido como la realidad misma. "El hombre necesita la verdad, un mundo que no se contradiga, que no falsee nada y que no cambie, un mundo-verdad, un mundo en el que no se padezca contradicción, ilusión, cambio, causas del sufrimiento. No duda un instante de que haya un mundo así, que deba haberlo"(V.P, $n^{\circ} 577,327 p$.). Fingimos un cosmos para ocultarnos el cambio porque éste nos arrastra, nos dispersa, nada se cumple, todo es imperfecto. El devenir es dispersión, olvido, fragmentación del individuo en la infinitud de los instantes.

El Nietzsche definitivo, que ha conjurado el pesimismo schopenhauariano, concibe el devenir como juego, juego del mundo que no busca otro fin que su propio ejercicio. "Si alguna vez jugué a los dados sobre la divina mesa de la tierra, de tal manera que la tierra tembló y se resquebrajó y arrojó resoplando ríos de fuego: pues una mesa de dioses es la tierra, que tiembla con nuevas palabras creadoras y con divinas tiradas de dados" (A.H.Z. Los siete sellos, 316 p.). Inmerso en su juego el niño heraclíteo no se pregunta el por qué de la existencia, en su goce tiene la respuesta. Juego sin sentido, sin finalidad, ateleológico, hecho sólo para fuertes, para las almas sanas, pero insoportable para los enfermos y débiles. "Ahí están los tuberculosos del alma: apenas han nacido, y ya han comenzado a morir, y ansían doctrinas de fatiga y de renuncia" (A.H.Z., De los predicadores de la muerte, 76 p.). Sólo hay verdadero pensamiento si renunciamos a las falsas seguridades, a la metafísica que secciona el devenir en instantes y busca relaciones de causalidad entre ellos, como si el tránsito de unos a otros revistiera carácter de imposición forzosa. Así se somete el devenir a una ley y se lo considera como modificación, actividad de un uno, idéntico y estable. Este algo subyacente vincula los instantes entre sí y les concede sentido en función de una finalidad, de este modo se oculta la muerte de cada instante, la desintegración de su irreductible individualidad. El momento no es ya un todo completo en sí, necesita justificarse a través de las conse- 
cuencias que le siguen; realidad acaba por identificarse con operatividad productiva, se hace equivalente a la capacidad para producir efectos.

Sobre dos ejes ha intentado la filosofía domesticar el devenir: el concepto de cosa y el de yo. Hay cosas, substancias, estabilidad, identidad. La piedad por los entes lleva a dividirlos en accidentes y esencia inmutable, de este modo el devenir sólo les afecta epidérmicamente. "La cosa en sí es absurda. Si todas las relaciones, todas las propiedades, todas las actividades de una cosa desaparecen, no queda la cosa, porque la coseidad es algo añadido por nosotros, por necesidades lógicas, con el fin de comprenderla" (V.P, $n^{\circ} 551,312 p$.). El lenguaje es el vehículo de este engaño. Somos platónicos desde el momento en que hablamos. La palabra no es sino la copia de una excitación nerviosa, pero nosotros deducimos de ella la existencia de una cosa fuera y la similitud entre cosas; en definitiva, detenemos el devenir con las palabras. Hipostasiamos la unidad del nombre por el que designamos un cierto conjunto de cualidades sensibles, concibiendo una sustancia, un en-sí, debajo de las apariencias móviles. Nietzsche no hace sino desarrollar la misma crítica que Hegel: la cosa no es un substrato simple que soportaría sin revelarse, las diversas cualidades sensibles, las diversas apariencias. La cosa es el resultado de la operación de unir un haz de experiencias, coordinar una serie de esbozos perceptivos en una totalidad, sobre la cual la acción pueda ejercerse eficazmente. Pero en el fondo la piedad por las cosas es piedad por el yo, también constituido en "cosa", en substancia. De esta forma el concepto de Yo enmascara esa forma propia del devenir que es el cuerpo y lo trata como si en él hubiera identidad. "Sujeto es la ficción que pretende hacernos creer que muchos estados similares son en nosotros el efecto de un mismo substratum pero somos nosotros los que hemos creado la analogía entre esos diferentes estados"(V.P., $n^{\circ} 480,279$ p.). Llamamos yo a lo que los demás esperan de nosotros y lo que nosotros esperamos de los demás. La existencia del hombre en sociedad sería inviable sin la previa fijación de las identidades que reciben el nombre de yo: las instituciones necesitan de la identidad personal a fin de que pueda darse la propiedad, promesa, contrato, falta, culpa, delito etc. No se puede prometer sin identidad del que promete (Cfr. "Genealogia de la Moral"). Todo ello convierte al hombre en un animal de ideas sencillas, reacciones simples y previsibles, de comportamientos prefijados. La ficción personal tiene una función de autocontrol y sometimiento. La sociedad imprime en el individuo el sello de la regla, éste al autocomprenderse realiza una acción violenta, quedando así toda comprensión de sí acomodada a los moldes sociales, todo nuestro ser cobra rigidez, nos forjamos una carácter y personalidad.

Pero el martillo del devenir rompe el yo: tan sólo la precaria ficción lingüística de un pronombre personal suelda con su engaño esta dispersión irre- 
ductible de las fracciones de nuestro ser. "Decir que, cuando se piensa, es preciso que haya algo que piensa, es un poco la formulación de un hábito gramatical que atribuye a la acción un actor"(V.P., $n^{\circ} 479,278$ p.). Vivimos en el instante fugaz, inocentes de toda culpa pasada, irresponsables ante cualquier tribunal futuro; este instante individual, inocente e irresponsable, es la respuesta nietzscheana al planteamiento de la subjetividad en la modernidad. El estricto presente de la existencia no carga ni con deudas del pasado ni acoge la responsabilidad del futuro. Los optimismos de tipo hegeliano que intentan descubrir en el devenir el cumplimiento de un canon moral elevado también lo desnaturalizan. La concepción nietzscheana es antiteleológica. El finalismo es el resultado de un antropomorfismo ingenuo y conlleva las nociones de falta y castigo. Desde el momento en que se pretende ligar el curso del mundo a un plan preestablecido, nos inclinaremos a admitir que si el estado ideal no se ha realizado todavía, la culpa es del hombre. Para explicar la ruptura entre el ser y el deber ser somos conducidos a pensar en un culpa que contraría a la providencia. Por ello negar el finalismo, negar al Dios que fija imperativos, negar el carácter ordenado, racional, moral del mundo, es sustraer el devenir a la peor de las maldiciones, es devolverle su inocencia: "En verdad, una bendición es y no una blasfemia el que yo enseñe: sobre todas las cosas el cielo Azar, el cielo Inocencia, el cielo Acaso y el cielo Arrogancia” (A.H.Z. , Antes de la salida del sol, 235 p.).

En el devenir no hay puntos estables, ni líneas continuas y uniformes. Hay dispersión, azar y falta de sentido. Que un instante suceda a otro es puro azar, nada hay en el primero que haga necesaria la sustitución por el segundo. En el estado A no hay ninguna compulsión que forzosamente le haya de conducir a transformarse en el estado B. "La causalidad se crea precisamente por el pensamiento, el cual introduce una constricción en el hecho de la sucesión. De esta menera surge una cierta comprensión, es decir, hemos humanizado el hecho, lo hemos hecho más conocido"(V.P, $n^{\circ} 657,361$ p.). Es la critica a la causalidad heredada de Hume. "Nada tenemos de una causa efficiens; aquí tiene razón Hume: el hábito nos hace esperar que un proceso observado frecuentemente sigue a otro: ¡Nada más!”(V.P.,n $n^{\circ}$ 543, 305 p.). Cada instante emerge en la frescura del olvido y en la fe en su ocaso. Hay un incensante renacer del mundo en el instante. Pero para el débil, el devenir significa: lo que amamos perece.

El antídoto lo constituye la fe en el más allá, el desdoblamiento de la realidad en mundo sensible y mundo inteligible. "Sufrimiento fue, e incapacidad, lo que creó a todos los transmundos; y aquella breve demencia de la felicidad que sólo experimenta el que más sufre de todos. Fatiga que de un sólo salto quiere llegar al final, de un salto mortal, una pobre fatiga ignorante, que ya no 
quiere ni querer: ella fue la que creó todos los dioses y todos los transmundos" (A.H.Z. De los transmundos, 57 p.). Desprovistos de todas las marcas del dolor, inteligibles y eternos constituyen el refugio contra la acción del tiempo. Su existencia se basa en el prejuicio parmenídeo de que lo que existe debe ser homogéneo con el pensamiento. En cambio el devenir es ininteligible, mezcla del ser y del no ser, destrucción de identidades y quiebra del principio de no contradicción ("lo que es, es y lo que no es, no es"). Por ello el devenir es apariencia, engaño de los sentidos. Sólo aquello que podemos iluminar con la razón es real. El cristianismo constituye una variante "popular" de esta filosofía, auténtico platonismo del pueblo. La existencia real es una degradación de la perfección divina. El ser absoluto denigra el devenir subsumiéndolo bajo el concepto de apariencia. Si abolimos el mundo-verdadero, también aboliremos el mundo como apariencia. "Todo lo imperecedero no es más que un símbolo. Y los poetas mienten demasiado. De tiempo y de devenir es de lo que deben hablar los mejores símbolos; una alabanza deben ser y una justificación de todo lo imperecedero" (A.H.Z., En las islas afortunadas, 133p.).

Hemos descubierto el devenir y rescatado las heridas que la existencia ha marcado en nuestra piel. Todo el proyecto nietzscheano apunta en esta dirección: restituir la escenografia, el espacio en el que surge el pensamiento. Las ideas remiten a un suceso que las desencadena. En este caso es el devenir. Frente a él, el cristianismo aparece como un dique de contención del terror, como un sistema de seguridad, de contención y anulación del azar, de la falta de sentido. "Cuando el agua tiene maderos para atravesarla, cuando puentecillos y pretiles saltan sobre la corriente: en verdad, alli no se cree a nadie que diga: todo fluye... En el fondo todo permanece inmóvil, esta es una auténtica doctrina de invierno, una buena cosa para una época estéril" (A.H.Z., De las tablas viejas y nuevas, 279 p.). Es la ideología de los pretiles, de las barandillas que impiden asomarse al abismo para que los débiles no se asusten. La religión, sistema de verdades frente a la verdad abismal e insoportable, remedio peor que la enfermedad. ¿Quién es su creador? ¿Quién la necesita? La genealogía nos muestra su origen oculto. La religión recubre una opción última sobre el ser: su identidad con el bien, identidad que garantiza el acuerdo entre las exigencias subjetivas del hombre y el absoluto. El hombre religioso no podría soportar que el mundo no estuviera ahí para él.

Nietzsche, recuperando la concepción heracliteana del devenir, no puede concebir el ser sino como cuestión. Pasamos así del monoteismo cristiano a un especie de politeísmo ("Esta es precisamente la divinidad, que existan dioses, pero no Dios" (A.H.Z. De las tablas viejas y nuevas, 281 p.)) que haga justicia a la movilidad absoluta de lo real. El idealismo sacraliza un ser momificado al que dota de todos los atributos que lo convierten en adversario de la vida y 
del devenir. Ser al que preserva en un más allá inmutable o como en-sí que se esconde tras las apariencias. Pero nuestro mundo es incierto, cambiante, variable, equívoco, un mundo peligroso. El ser que deviene no puede permanecer cautivo de nuestras categorías racionales: "Lo que puede ser pensado es ciertamente ficticio" El ser es cuestión, o si queremos, interpretación. De este modo se conserva su carácter ambiguo, su inconmesurabilidad: "El mundo es profundo, más de lo que el día imagina". El ser transciende a la razón. "En todas las cosas sólo una es imposible: la racionalidad. Un poco de razón, ciertamente, una semilla de sabiduría, esparcida entre estrella y estrella, esa levadura está mezclada en todas las cosas: por amor a la necedad hay mezclada sabiduría en todas las cosas. Un poco de sabiduría sí es posible; más ésta fue la bienaventurada seguridad que encontré en todas las cosas: que prefieren bailar sobre los pies del azar" (A.H.Z. Antes de la salida del sol, 235 p.). No se trata de desvalorizar la razón: el ser no es razón absoluta ni sinrazón, sólo autoriza una afirmación: está abierto al pensamiento, pero este compromiso no conduce a su posesión. La reflexión alcanza al ser pero no coincide nunca con él, no es el ser un logos translúcido. El es un límite que asigna una tarea infinita.

El perspectivismo se apoya en el ser que deviene y que al devenir se muestra de mil maneras. Se acaba así con la creencia metafísica en una subjetividad capaz de dominar la totalidad del ser. El sujeto que conoce está situado y sólo puede concebir perspectivas parciales que no agotan la riqueza de lo real. "La tarea: ver las cosas tal como son. El medio: contemplarlas a través de cientos de ojos, a través de numerosas personas" Nietzsche defiende con ello un pluralismo ontológico: el ser tiene por esencia mostrarse, pero mostrarse según una infinidad de puntos de vista. Nuestra experiencia es la de un ser desgarrado en el infinito parpadeo del universo, que se comporta como un texto susceptible de múltiples lecturas. Texto obscuro, lagunar, que pide la interpretación como iniciativa creadora de quien interpreta. Por eso lo que consideramos el ser es un producto cultural, un monumento de la civilización humana.

El ser es texto, no un conjunto de ideas claras y distintas, no racionalidad omnipresente, sino inteligibilidad obscura, no plena luz del sentido, sino un estremecimiento de éste, una serie de alusiones discretas. La interpretación es la expresión de ese parpadeo (devenir) ontológico irreductible que excluye la síntesis superior de los diferentes puntos de vista particulares. Es el existente el que constituye el sentido del texto por una operación que le compromete radicalmente, porque la relación de la interpretación con el texto no es del orden de la contemplación sino del combate y de la conquista. Son nuestros instintos prácticos los que nos imponen una interpretación que nos permita subsistir en un mundo de signos y superficies, generalizado, vulgarizado. Lo 
real nos reenvía la imagen de nuestros deseos, de nuestros miedos, de nuestras esperanzas y elecciones fundamentales. Es el correlato de todos nuestros actos de proyección. “ ¿Y si nuestro yo fuera el único ser a semejanza del cual creásemos o comprendiésemos todos los seres perfectamente?" (V.P., $n^{o}$ 512, 291 p.).

Nietzsche aleja la amenaza del dogmatismo religioso insistiendo sobre la imposibilidad de una interpretación definitiva que agotaría la riqueza de lo real: el ser es equívoco, no hay verdad absoluta que el hombre poseería como un bien inalienable. Pero contra el relativismo absoluto, niega el derecho de escamotear el texto y substituirlo por la idea de un caos fundamental que podría recibir cualquier interpretación. El texto existe y todas las perspectivas no son igualmente legítimas. Para Nietzsche caos quiere decir que el ser no es reductible a un ideal humano. El caos designa el poder plástico de la vida en lo que tiene de inhumano, de terrible, de indomable. Nietzsche libera a la naturaleza de las interpretaciones demasiado humanas, la deshumaniza al desdivinizarla. Substituimos el logos del idealismo por el caos de la vida dionisiaca.

La realidad es realidad interpretante y realidad interpretada. Si se acentúa la noción de interpretación, el aspecto creador, dominador, somos conducidos a la doctrina del pragmatismo perspectivista según el cual conocer es introducir un sentido en el mundo para plegarlo a nuestros imperativos vitales. Conocimiento es anexión, apropiación, voluntad de regir lo real. Pero, por otra parte, si nos preocupamos del lado objetivo de la interpretación somos conducidos a contestar la validez última del criterio de utilidad vital. El texto no es un juguete de la subjetividad humana. Para los espíritus más nobles y más valientes, una voz habla más alto que la voz del imperialismo vital y esta voz manda hacer justicia a la naturaleza, revelar las cosas tal como son. La probidad filológica anima la auténtica pasión por el conocimiento que prefiere las verdades desoladoras a los ideales falaces. Este examen nos entrega la doble afirmación de que la verdad tiene por medida el valor para la vida y que, sin embargo, la verdad reclama esta filología rigurosa que inmola el valor a la justicia. La realidad es devenir, lucha, contradicción, dolor: estos son los atributos que provocan su condenación en la voluntad decadente. Esta realidad calumniada por la religión y la metafísica designa ahora el texto que Nietzsche recupera a través de los principios de una filología severa. Pero, además, el mundo designa ese conjunto de interpretaciones con las que los hombres petrificamos el devenir, el mundo en el que podemos vivir: su verdad coincide con su valor para nosotros. Necesitamos de las ilusiones.

Para concluir: el devenir es la esencia de lo real. De esta manera lo real se constituye en pura movilidad y pura temporalidad. Como tal, el ser es equi- 
vocidad que sólo puede fundamentar una interpretación politeista del mismo. No hay lugar al dogmatismo cristiano. Este sólo representa un intento de acondicionarse un mundo del que se habría evacuado su esencia, un mundo paralizado donde los espíritus débiles podrían vivir a gusto. Pero este mundo paralizado es la nada. El terror que el devenir infunde en cierto tipo de almas está en el origen "genealógico" de la religión. Este es el sentido del cristianismo.

\section{EL CUERPO TROCEADO}

No es sólo la filosofía del devenir cósmico la que presenta querella contra el cristianismo, también la concepción del cuerpo como realidad segunda y la primacia de la conciencia y el alma. Una y otra forman parte de la estrategia para borrar el cuerpo como signo de lo caduco, de lo mortal, de la imperfección, del instinto. La operación del cristianismo consiste en extirparlo por la identificación del yo con el alma. Vamos ahora a estudiarlo.

El cuerpo es un abismo del que no se posee la llave. Así el miedo ante lo desconocido es también miedo ante el cuerpo: angustia por la complejidad de fuerzas que lo constituyen, ante las pulsiones no controladas e inconfesables, opacas al libre arbitrio. De golpe la alteridad no tiene ya la figura lejana del cosmos. Mi propio cuerpo, yo mismo, soy otro. "Nosotros los que conocemos somos desconocidos para nosotros, nosotros mismos somos desconocidos para nosotros mismos: esto tiene un buen fundamento... Cada uno es para sí mismo el más lejano" (G.M., $n^{o} 1,17$ p.). Seguramente este abismo que cada uno es para sí, podría no suscitar espanto en un ser capaz de querer y afirmar la alteridad. Pero en la mayoría esta alteridad genera miedo y resentimiento.

El hombre dividido en sí mismo, ansioso ante la vida que él es, desea borrar lo extraño, negarlo concediendo unidad y transparencia a la realidad corporal, de modo que la alteridad se convierta en secundaria. Lo horrible para la voluntad débil no es sólo el devenir cósmico, sino ese devenir interiorizado que es el cuerpo. La religión tiene a ambos escenarios como matriz. Nos defiende contra la angustia de un cuerpo cuyos instintos amenazan con anegar la conciencia, conjunto de pulsiones parciales que se desbordan, amenazando con hundirnos en la locura. El Yo, decía Freud, no es un señor en su morada. También lo piensa Nietzsche.

Partir de la conciencia conduce a formarse una representación superficial de la vida, aceptar la ruptura entre cuerpo y alma y el idealismo. Este eleva la conciencia a absoluto, haciendo de ella una sustancia sui generis, el alma, cuyo valor ontológico es eminente, mientras se reduce el cuerpo a 
envoltorio contingente. La esencia del hombre se confunde con esta alma sobrenatural, emparentada con el mundo inteligible y la divinidad. Nietzsche denuncia la idea de que la conciencia agote la esencia del hombre. Hay que enseñarle humildad: ella es un simple auxiliar de la razón del cuerpo. "Todos nuestros motivos conscientes son fenómenos de superficie: detrás de ellos se desarrolla la lucha de nuestros instintos y de nuestros estados: la lucha por el poder"7. Así el fenómeno consciente sostiene con las operaciones del sí orgánico una relación de significado a significante. "Nada llega a la conciencia que antes no hay sido completamente modificado, simplificado, esquematizado, interpretado". De ahí la pobreza esencial de la interioridad, espejismo de lo profundo, de lo corporal. La observación interna, la introspección, fracasa en la labor de captar la realidad profunda del psiquismo y por eso la conciencia es incapaz de criticarse a sí misma. "Lo que se hace consciente se encuentra en relaciones de causalidad que nos son absolutamente desconocidas"(V.P., $n^{\circ}$ 518,295 p.). Nietzsche se aproxima a Freud. El yo-substancia, productor espontáneo del pensamiento es una ficción, jamás en el flujo de la conciencia nos encontramos con tamaña entidad. "Todo lo que entra en la conciencia bajo forma de unidad es ya extremadamente complejo; no captamos jamás más que una apariencia de unidad, si hay alguna unidad en mí, no consiste ciertamente en el yo consciente, en el sentir, el querer, el pensar, ella está en otra parte, en la sabiduría global de mi organismo, ocupado en conservarse, en asimilar, en eliminar, en vigilar el peligro; mi yo consciente no es más que un instrumento para ello. La sensibilidad, la voluntad, el pensamiento jamás me enseñaran sino fenómenos terminales cuya causa me es desconocida; la sucesión de estos fenómenos terminales que parecen resultar los unos de los otros no es sin duda más que una apariencia" 8.

Nietzsche atribuye el pensamiento al cuerpo entero, pensamiento corporal inconsciente, mucho más sabio y rico que el de la conciencia. Esta desempeña una tarea auxiliar y derivada. "Las funciones animales resultan mucho más importantes que todos los bellos estados de ánimo y la altura de la conciencia; éstas son cosas superfluas, en cuanto no deben ser instrumentos de aquellas funciones animales. Toda la vida consciente, el espíritu juntamente con el alma, con el corazón, con la bondad, con la virtud, ¿al servicio de quiénes trabajan? Trabajan en favor del mayor perfeccionamiento de los medios de nutrición y educación de las fundamentales funciones animales: sobre todo del incremento de la vida. Por tanto la parte incalculablemente mayor se encuentra en lo que se llama cuerpo: el resto resulta accesorio" (V.P., $n^{\circ} 667,366$ p.). El

7. GRENIER,J. o.c., p.133. Es una cita de "Obras Póstumas".

8. GRENIER,J, J. o.c., p.137. Es una cita de "La Voluntad de Poder". 
cogito reflexivo es víctima de una ilusión: la interioridad que él discierne no agota jamás la riqueza profunda de la vida psíquica. Para descubrirla hay que situarse en otro punto de vista: la gran riqueza orgánica. Si disipamos el espejismo de la interioridad metafísica y consideramos el fenomenismo del yo, se puede decir que el ser de nuestros pensamientos desborda el aparecer reflexivo y reenvía, más allá del ego, a una subjetividad orgánica. El cogito lejos de constituir el ser de sus ideas, es él mismo constituido en el cuadro de una espontaneidad vital que Nietzsche designa como "instintos", verdaderos motivos inconscientes de actuación. Las motivaciones conscientes son fenómenos superficiales del cogito. Pero la teología necesita el concepto de voluntad libre para explicar el mundo del devenir como una degradación causada por la caida del hombre. Hay que creer que el hombre es soberano de lo que piensa, que todo en él es conciencia. Así asume la responsabilidad del mal en lugar de Dios: la creación es buena, pero el mal existe porque el hombre es libre. El hombre debe ser declarado responsable e infectado con las ideas de culpa y castigo. "La voluntad del hombre de encontrarse culpable y reprobable a sí mismo hasta resultar imposible la expiación, su voluntad de imaginarse castigado, su voluntad de infectar y de envenenar con el problema de la pena y la culpa el fondo más profundo de las cosas, su voluntad de establecer un ideal, el del Dios santo, para adquirir en presencia del mismo, una tangible certeza de su absoluta indignidad... iQué bestialidad de idea!" (G.M., $n^{\circ} 22,106$ p.).

En la consideración del cuerpo Nietzsche muestra claramente su preocupación por lo sano y lo enfermo. Salud es sobre todo salud del cuerpo. Si Dioniso ataca al crucificado es porque hay un cuerpo dionisíaco sano afirmador de la vida, frente a un cuerpo cristiano enfermo, decadente, que se autodesprecia: "El cristianismo que desprecia el cuerpo, ha sido hasta ahora la mayor desventura de la humanidad". La afirmación del cuerpo en toda su abismalidad necesita de la muerte de Dios, espectador culpabilizante y compasivo, por eso es el hombre más feo el que mata a Dios, aquel que despertaba compasión pero que ahora quiere afirmar su cuerpo. "Su compasión carecía de pudor: penetraba arrastrándose hasta mis rincones más sucios. Ese máximo curioso, super-indiscreto, super-compasivo, tenía que morir. El hombre no soporta que tal testigo viva. Así habló el más feo de los hombres" (A.H.Z., El más feo de los hombres, 357p.). Sólo tras la muerte de Dios recupera el cuerpo su inocencia. Es más, un cuerpo vigoroso no necesita de Dios para subsistir: "Se ha llamado Dios a todo lo que debilita, a todo lo que predica la debilidad, a todo lo que infecta de debilidad" (V.P., $n^{\circ} 54,58$ p.). Nietzsche nos llama a oir la voz del cuerpo poderoso y sano, ella manda amar la vida tal como es, evitar la fuga de los transmundos: "Es mejor que oigáis, hermanos míos, la voz del cuerpo sano: es esta la voz más honesta y más pura. Con más honestidad y 
con más pureza habla del cuerpo sano, el cuerpo perfecto y rectangular; y habla del sentido de la tierra" (A.H.Z. De los transmundos, 59 p.). El cuerpo vigoroso es abogado de la inmanencia del mismo modo que los despreciadores del cuerpo son los inventores del más allá: "Pero cosa enfermiza es para ellos el cuerpo: y con gusto escaparían de él. Por eso escuchan a los predicadores de la muerte, y ellos mismos predican trasmundos".

El cuerpo fuerte desarrolla una gama de funciones sutílisimas, de una manera más perfecta que la razón misma. La subjetividad global del cuerpo es el resultado de una multitud de fuerzas solidarias, jerarquizadas. Multitud de instintos y pulsiones, auténticas subjetividades orgánicas, investidas de energía y cuyo trabajo se efectúa en las profundidades del sí corporal. " $E l$ cuerpo es una gran razón, una pluralidad dotada de un único sentido, una guerra y una paz, un rebaño y un pastor. Instrumento de tu cuerpo es también tu pequeña razón, hermano mío, a la que llamas espíritu, un pequeño instrumento y un pequeño juguete de tu gran razón. Dices "yo" y estás orgulloso de esta palabra. Pero esa cosa más grande aún en la que tú no quieres creer, tu cuerpo y su gran razón: esa no dice yo, pero hace yo". (AHZ, De los despreciadores del cuerpo, 60 p.).

Sin embargo el decadente y enfermo carece de instintos firmes y se ha de apoyar en la conciencia y la razón. La hipertrofia de lo racional compensa sus carencias. Es el caso de Sócrates: "Deformación: la ironía de sí mismo, la sequedad dialéctica, la inteligencia como tirano contra el tirano (el instinto). En Sócrates todo es exagerado, excéntrico, caricatura, un bufón con los instintos de Voltaire" (V.P.n 426, 250 p.). La razón orienta, mientras que el cuerpo y su sabiduría extravían. El cuerpo es malo, sus pasiones nos atan al devenir y fragilizan la existencia. Sócrates y Platón son los primeros en pensar que la felicidad sólo es posible a costa de sacrificar una parte de nosotros mismos. No somos cuerpo, sólo lo tenemos y ello bajo la égida del alma. Una parte de nosotros está contra nosotros. Por eso la filosofía es aprender a morir (Fedón) y la vida una enfermedad. En esta tradición bebe el cristianismo.

¿Cómo se niega el cuerpo? Afirmando el alma, substancia del yo, negadora de los instintos que nos poseen y fragmentan. El alma divina es algo que somos, el cuerpo sólo algo que tenemos. Nos substraemos así a la entropía de todo lo real y afirmamos el más allá como remedio a nuestra finitud. Es la estrategia del hombre enfermo, de la vida que no puede soportar la vida. Cuando los instintos no son fuertes, tiene que venir dios en ayuda del hombre.

Frente al cuerpo humillado en su contraposición al alma, Nietzsche reivindica el cuerpo dionisíaco liberado de culpa, un cuerpo que desea su despedazamiento sin temerlo, que quiere la resurrección de lo instintivo. Ya Freud 
descubrió lo perverso como esencial a lo humano. Es la sexualidad infantil en toda su perversidad que perdura, intemporal, en el inconsciente. Hay por eso más en el cuerpo de lo que imaginamos. La angustia es el resultado de ese más, del ataque pulsional interno del que la instancia unificadora del yo a penas puede defenderse.

El cuerpo mantiene su coherencia reuniendo todas las pulsiones parciales y sublimándolas. Si se rompe esta estructura centralizada, se fractura su unidad. Hay en Nietzsche una recuperación de la polimorfía en cuanto denuncia de la sujección a la cabeza y de la represión de nuestra "animalidad" por la conciencia. "En otro tiempo tenías pasiones y las llamabas malvadas. Pero ahora no tienes más que tus virtudes: ellas han surgido de tus pasiones" (A.H.Z. De las alegrías y de las pasiones, 64 p.). Si el yo así concebido, bajo el imperio de la razón, se rompe, el cuerpo se libera. Por eso al atacar al yo, se defiende un cuerpo polimorfo. No es el cuerpo glorioso del cristianismo, cuerpo no castrado, con sus órganos sexuales, pero sin funciones. Esta mística cristiana supone el horror al cuerpo real, castrado, imperfecto, pluralidad de impulsos. Nietzsche se nos muestra provocador y subvertidor. Pero sabe que el instinto liberado ha de ser sublimado. No se trata de abandonar al hombre a un hedonismo de pocas miras. "La gente tiene su pequeño placer para el día y su pequeño placer para la noche” (A.H.P. Prólogo, 40 p.). Somos esencialmente transcendencia, no como asalto al cielo preexistente, sino como permanente creación, como vuelo que al elevarse crea él mismo un horizonte. Las verdades no bajan del cielo, suben de la tierra impulsadas por el hombre sano, nacen de la vitalidad de su cuerpo, de la fuerza de sus instintos: "Tú Zaratustra has querido ver el fondo y el transfondo de todas las cosas por ello tienes que subir por encima de tí mismo, arriba, cada vez más alto, hasta que incluso tus estrellas las veas por debajo de ti”” (A.H.Z., El viajero, 221 p.).

Lo espiritual no es sino el lenguaje cifrado del cuerpo. "El cuerpo creador se creó para sí el espíritu como una mano de su voluntad” (A.H.Z. De los despreciadores del cuerpo, 61 p.). La intencionalidad de la conciencia está sostenida en el ser por una transcendencia más originaria, el sí del cuerpo, multiplicidad de instintos, auténticos centros de interpretación, microcosmos de la voluntad de poder. Ellos juzgan, desean, eligen, mandan... Es la inteligencia de los instintos la que garantiza la sabiduría del sí, el depositario de nuestra verdad más personal. "Detrás de tus pensamientos y sentimientos, hermano mío, se encuentra un soberano poderoso, un sabio desconocido, llamado el símismo. En tu cuerpo habita, es tu cuerpo. Hay más razón en tu cuerpo que en tu mejor sabiduría” (A.H.Z. De los despreciadores del cuerpo, 61 p.). A la astucia de la razón hegeliana, Nietzsche sustituye la astucia del instinto: "Tú sí mismo se ríe de tu yo y de sus orgullosos saltos. ¿Qué son para mi esos saltos 
y esos vuelo del pensamiento? Un rodeo hacia mi meta". (A.H.Z. idid.). El debilitamiento del sí corporal obliga a confiar en el yo racional y a renunciar a la sabiduría del cuerpo.

Pero Nietzsche no es un discípulo de Calicles para quien la liberación del hombre consiste en desencadenar los apetitos sensuales. Nietzsche escribe: "El placer es sólo un síntoma del sentimiento del poderío alcanzado, la comprobación de una diferencia; no se busca la consecución del goce, el goce sobreviene cuando se logra lo que se pretende: el goce acompaña pero no mueve” (V.P., $n^{\circ} 681,377$ p.). El poder es la medida de su aptitud para transcenderse y en este transcendimiento el hombre engendra algo superior a sí mismo: el superhombre. A este engendramiento acompaña el placer, como su signo, como expresión de la voluntad de poder. Entonces el hombre debe perecer en su ocaso, como el sol en el horizonte, él es puente hacia otra cosa. "Yo amo a los que no quieren preservarse a sí mismos. A quienes se hunden en su ocaso los amo con todo mi amor: pues pasan al otro lado" (A.H.Z. De las tablas viejas y nuevas, 278 p.). La vida es un esfuerzo siempre mayor de poder, pero este plus no representa un acrecentamiento objetivo de un capital de fuerza sino la ilimitación propia del acto de transcenderse. "El poder de la clase media se conserva por el comercio, sobre todo por el comercio del dinero... Pero su propio instinto es fatalmente conservador y mediocre" (V.P. $n^{o} .859,470$ p.). Lo esencial no es el aumento de bienes sino el grado de disciplina que un ser es capaz de inflingirse para extraer de sí lo imposible: "Quien se ha tratado a sí mismo con mucha indulgencia acaba por enfermar a causa de ello" (A.H.Z. El viajero, 220 p.). La voluntad de poder es menos deseo de algo que deseo de desear ("Haced lo que queráis con tal de sepáis querer"). Es en el deseo donde cada uno puede reconocer la traza fugitiva de su transcendencia. El acto de transcenderse a sí mismo no puede disociarse del fervor creador, de la prodigalidad, del heroismo lúcido con los cuales debe operarse el compromiso del hombre en la tragedia de la historia. Por eso Nietzsche no tiene más que menosprecio para el hedonismo de Calicles. No se trata de abandonarse al placer de los instintos, sino de aumentar la dureza de la existencia para obligar al hombre a plegarse a una disciplina siempre más austera. Pero tampoco es un socrático. Reencontramos la oposición categórica entre la domesticación del hombre obtenida gracias al aplastamiento de las pulsiones peligrosas y la verdadera cultura humana que exige la sublimación de todas las energías vitales. No sirve de nada combatir el hedonismo de Calicles si se lo sustituye por el mortificación de Sócrates. Antes prefiere Nietzsche al bárbaro de pasiones brutales que al animal gregario, débil, que se conduce según los principios de la moral ascética y que al imponer al hombre la tarea de extirpar las pasiones borra la posibilidad de transcendencia. Esta es la ética cristiana, terroris- 
mo nihilista, moral de la anihilación de sí. Según que el acto de sobrepasarse se cumpla por la liquidación de los instintos o por su superación, la voluntad de poder caerá en la decadencia o se desarrollará en la vida ascendente.

Contra el hedonismo, la naturaleza es superación de sí y no complacencia en sí. "La preponderancia del dolor sobre el placer o lo contrario (el hedonismo): estas dos doctrinas son ya indicios que apuntan al nihilismo... Porque, en ambos casos, no se establece aquí ningún otro sentido último sino la apariencia del placer o el desplacer. Pero asi habla una clase de hombres que ya no se atreve a establecer una voluntad, una intención, un sentido; para cualquier clase de hombres más sana el valor de la vida no se mide así" (V.P. n³5, 46 p.). Contra la moral clásica, la superación de sí es paso, y no divorcio de uno consigo mismo. "Sublimar todos los impulsos de modo que pueda llevarse muy lejos la sensibilidad para lo que es extraño y hacer de ello, a pesar de la extrañeza, una fuente de gozo. El instinto de sinceridad respecto de sí mismo, el de justicia respecto de las cosas debe convertirse en tan fuerte que sus gozos sobrepasen las otras formas de gozo que deberán quizá serle sacrificados, parcial o enteramente"9. Esta sublimación representa una espiritualización o una intelectualización de las tendencias vitales. La sublimación es una auténtica transcendencia que mantiene lo que sobrepasa elevándolo a una forma superior (Hegel). Un instinto sublimado aparece como necesariamente opuesto al instinto bruto, refleja la promoción de este instinto en el orden de la razón: "Cuando un instinto se intelectualiza, le damos un nombre nuevo, le prestamos una apreciación nueva, ejerce funciones nuevas. Frecuentemente lo oponemos al mismo instinto tal como se manifiesta en el plano inferior, como si él fuera la antítesis"10.

La sublimación actúa complicando el circuito de la excitación y de la reacción, retardando la explosión vital primaria y enseñando al instinto la paciencia del rodeo: “Problema: ¿cómo el querer, el temible querer será decantado y purificado, es decir, transcendido, convertido en tendencias más elevadas? Por medio de un cambio llevado al mundo de la representación, por el gran alejamiento de su fin, alejamiento tal que este querer debe ennoblecerse en un despliegue inmenso"11. Así se suaviza el instinto, se le substrae su carácter intempestuoso. La sublimación lo transforma haciéndolo flexible, plástico, moldeable. Si la voluntad de poder es el acto de transcenderse a sí mismo, es decir, la sublimación, entonces es esencialmente voluntad de cultura. "El querer hace libres: pues querer es crear: así enseño yo. $Y$ sólo para crear debéis

9. GRENIER,J, J. o.c., p. 423. Es una cita de "Obras Póstumas".

10. GRENIER,J, J. o.c. p. 424. Cita de "Obras Póstumas".

11. GRENIER,J, J. Ibidem. Cita de "Fragmentos sobre la energía y el poder". 
aprender" (A.H.Z. De las tablas viejas y nuevas, 285 p.). No hay que equivocarse, poder no es violencia y dominación sobre el otro. Lo que Nietzsche exalta es la dominación sobre sí, el heroismo del conocimiento y la sublimación estética de los instintos en detrimento de la violencia bárbara, característica del individuo vulgar y mediocre. "Yo encontré la fuerza donde no la buscaba, en los hombres simples, dulces y exigentes, sin la menos inclinación al dominio, e inversamente el gusto de dominio no aparece frecuentemente sino como un signo de debilidad íntima... Las naturalezas fuertes, es una necesidad, reinan, sin tener necesidad de levantar un dedo"12.

Resumimos lo dicho. La filosofía del cuerpo constituye un nuevo motivo en la querella de Nietzsche contra el cristianismo. La decadencia de lo corporal está en el transfondo de la génesis de lo religioso. El alma se convierte en sujeto de la fe a costa de un cuerpo mortecino. Es el cuerpo enfermo el que cree, el que, perdida su seguridad instintiva, necesita a Dios. Y en Dios se opera la gran venganza de lo débil hacia lo fuerte, la venganza de lo enfermo. Porque él es la manifestación del resentimiento, de la agresividad, de la moral como ataque a lo que está vivo y es poderoso. Aquello que el creyente no puede tener lo ataca en el otro hasta subyugarlo.

\section{LA RELIGIÓN COMO SÍNTOMA}

Para Nietzsche la religión es un fenómeno escrito en clave cuyo significado es necesario desvelar. Al modo de los sueños en Freud, el cristianismo nos ofrece un material manifiesto que nos remite a un contenido latente que hay que sacar a flote. Sólo así comprenderemos por qué la religión se hace necesaria para cierto tipo de personas. Esta es el pregunta clave: ¿quién necesita de la religión?

Las ideas existentes no son sino fenómenos que requieren ser descifrados. Y la clave de su comprensión se da en el desvelamiento de su origen, tarea que Nietzsche llama genealogía. ¿De qué origen son fenómeno y síntoma? La religión, como la metafísica, es tratada por Nietzsche como un epifenómeno, un pensamiento que ha olvidado sus premisas existenciales. El análisis genealógico se acerca a la crítica de la ideología en Marx. En uno y otro la religión deja de ser considerada como un conjunto de datos inmediatos que se dejan comprender desde sí mismos. Marx ve en la superestructura la manifestación de una praxis material. Nietzsche habla de la religión como síntoma de una actitud ante la vida. En los dos casos la apelación al fundamento onto-

12. GRENIER,J, J. o.c. , p. 402. Cita "La voluntad de poder". 
lógico suprasensible es eliminado en favor de una búsqueda de lo originario en el corazón de la inmanencia: "No es la conciencia la que determina la vida, es la vida la que determina la conciencia".

Una crítica puramente especulativa de la metafísica y la religión hace el juego a ambas: "Hasta el presente el asalto dado al cristianismo es no sólo tímido sino falseado... El único problema de la verdad del cristianismo, la existencia de su dios o la historicidad de su leyenda, por no decir nada de su astronomía y de su ciencia de la naturaleza, es un problema muy accesorio mientras no se cuestione el valor de la moral cristiana"13. La aplicación de la metodología genealógica tiene por finalidad disipar la ilusión de una autonomía de la actividad predicativa refiriendo todos los juicios a sus condiciones de existencia. Marx escribe: "Exigir que se renuncie a las ilusiones que conciernen a nuestra propia situación, es exigir que se renuncie a una situación que tiene necesidad de ilusiones". Pero no se refutan condiciones de existencia, sólo se las puede cambiar. Para Nietzsche la problemática del origen es sobre todo una problemática moral. La razón de las razones no se encuentra en la argumentación misma sino en los juicios de valor que vehicula el cristianismo. Como hace notar E. Fink, en Nietzsche, tras la metafísica se esconde la moral y detrás de ésta una manera de valorar la vida. Las morales representan modos de existencia de los que juzgan y valoran. El problema crítico por excelencia es el del valor de los valores. Los hay en los que sólo se puede creer a condición de vivir y pensar bajamente. He aquí lo esencial: lo alto y lo bajo, lo noble y lo vil. La genealogía es la investigación del origen noble o vil de los valores.

Para Nietzsche vivir es evaluar. Todo individuo posee la aptitud de crearse una tabla de valores que traduce sus aspiraciones. "Una tabla de valores está suspendida sobre cada pueblo. Mira, es la tabla de sus superaciones; mira, es la voz de su voluntad de poder" (A.H.Z., De las mil metas y de la única meta, 95). La moral está enraizada en tendencias obscuras de la vida orgánica, por eso glorifica a un tipo determinado de vivientes. Detrás de ella aparecen las estructuras existenciales que constituyen un tipo orgánico: "una creencia expresa en general la fuerza obligatoria de ciertas condiciones de existencia, la sumisión a la autoridad de las únicas circunstancias en las cuales un ser puede prosperar, crecer, adquirir poder". El punto de vista del valor consiste en prever las condiciones de conservación y crecimiento para los seres en el interior del devenir. La ecuación es: moral = normatividad vital $=$ creencia $=$ código cifrado de condiciones de existencia = semiología de los instintos. El inmoralismo nietzscheano cobra aquí su sentido. No se trata de prescindir de toda moral sino de transcender la que está implícita en la tradición metafísica y en

13. GRENIER,J, J. o.c., p. 155. Cita "La voluntad de poder". 
la religión."Oh hermanos míos, hay tablas que las creó la fatiga, y las tablas que las creó la pereza, tablas perezosas" (A.H.Z. De las tablas viejas y nuevas, 287 p.).

El estudio genealógico de la religión establece los valores que ésta oculta, para determinar el tipo existencial que se expresa en ese código abstracto. Finalmente tras el tipo hay una jerarquía de instintos. Por ello la pregunta concernirá al tipo de fuerza, de energía que favorece o reprime, a su capacidad de volver al hombre más sano o enfermo. Y la salud o la enfermedad hacen referencia a una manera de vivir el sentido del ser. Este es el punto último y más fundamental. Y de acuerdo a él Nietzsche distingue:

a. El ideal superior que corresponde al máximo de salud física y psíquica. Reflejo de una vida creadora que se derrama en su exceso de riqueza.

b. El ideal inferior que es expresión de una vida anémica incapaz de dominar lo real y de asumir sus aspectos más terribles (el devenir). Está obligado a seleccionar y espiritualizar. Es el caso de las castas sacerdotales.

c. El ideal nihilista corresponde a una vida tan enferma que no puede soportar el contacto con lo real y hace del ideal una negación de la realidad.

Es el pesimismo de nuestros contemporáneos.Con la ayuda de la filosofía del martillo (la ironía crítica) el valor deja de ser un absoluto para convertirse en síntoma de la experiencia del ser como profusión o indigencia. Entonces la búsqueda de la esencia de un sistema metafísico o religioso acaba en una imputación. Es la pregunta por el quién: ¿Qué voluntad tiene necesidad de tal sistema para apropiarse el ser? Toda filosofía se arraiga en el proyecto de un determinado existente, razón de las razones, sentido de la esencia de cualquier sistema de ideas. Esta manera de cuestionar que acaba siempre en el "quién" refleja la modificación revolucionaria que Nietzsche opera sobre la esencia en filosofía.

La metafísica convierte la axiología en una topología: un valor superior tiene su fundamento en un lugar superior y un valor inferior es siempre de extracción inferior, procede de lo sensible. El hombre moral no puede tolerar la mezcla y necesita de la catarsis: hay que purificar lo real disociando el ser de la apariencia, la inteligencia de lo sensible, lo espiritual de lo corporal. La mezcla es mancha. Así el pensamiento religioso y metafísico desconoce esta determinación esencial de lo real rompiendo la convivencia solidaria de lo positivo y lo negativo. No puede tolerar que los valores más altos estén mar- 
cados por el devenir y la materia. El pensamiento metafísico hace de la ambigüedad, las modificaciones, el cambio, una experiencia engañosa. Los elementos antagonistas son separados para constituir sistemas irreductibles: uno es real, lo inteligible y el otro una apariencia, lo sensible. Es la génesis del dualismo, esencial al cristianismo y al platonismo. Según él, el bien se opone radicalmente al mal. Su conjunción es resultado de una corrupción causada por una falta ético-religiosa. Miedo al devenir, a los instintos, nostalgia de un estado de quietud que dispense del esfuerzo y la creación. "Lo sabes bien: el demonio cobarde que hay dentro de tí, a quien le gustaría juntar las manos y cruzarse de brazos y sentirse más cómodo: ese demonio cobarde dice: ¡Existe Dios!” (A.H.Z. De los apóstatas, 254 p.).

El hombre moral, bueno, necesita el dualismo ya que es impotente para integrar lo negativo en la maduración de su persona. "Cuanto más mediocre, débil, servil, cobarde, es un hombre, más cree en el mal, es en él que el dominio del mal está más extendido"14. El mal es la deformación de lo negativo en la conciencia del hombre bueno que no quiere comprender que lo negativo es el auxiliar irreemplazable de toda voluntad de creación. No hay transcendimiento del hombre si se rechaza lo contradictorio del centro del individuo. Es la lucha entre el ser dado y el yo superior que trabaja para elevar esta naturaleza a la altura de sus exigencias: "Es preciso tener caos dentro de sí para poder dar a luz una estrella danzarina. Yo os digo: vosotros teneis todavía caos dentro de vosotros" (A.H.Z.Prólogo, 39 p.). El hombre bueno proyecta el caos fuera de sí para protegerse del esfuerzo de autosuperación. Quiere lo que él es, suprimir la tensión que le obliga a cruzar el puente. Simplemente desea instalarse en la existencia con toda comodidad. El hombre de la moral es el hombre del tener, no el hombre del devenir. Nietzsche piensa lo negativo como función mediatriz en la producción del hombre por sí mismo. El mal es el dolor del alumbramiento, la crueldad de la metamorfosis, la angustia de la transfiguración. A la piedad, que es un trasvestimiento de la vana complacencia en sí, opone el gran desprecio por el cual el hombre se contesta sin cesar y rechaza el narcisismo de la mala finitud. "Mi yo es algo que debe ser superado: mi yo es para mí el gran desprecio del hombre" (A.H.Z. Del pálido delincuente, 67 p.). El desprecio es el resultado de la conciencia del hombre que se quiere siempre delante de sí y que es consumido por la pasión de la victoria sobre sí, cuyo precio es la crueldad hacia uno mismo. Si el hombre es indisolublemente materia y forma, acto de elevar un naturaleza bruta a un grado de perfección superior, entonces tomar partido por la piedad es favorecer lo que, en el hombre, debe ser sacrificado al querer creador, es elegir el caos, lo infor-

14. GRENIER,J, J. o.c., p. 178. Cita "La voluntad de poder". 
me contra la potencia plástica creadora de formas. La virtud auténtica no nos protege, nos empuja al abismo por la prodigalidad: "Conocéis las chispas que arroja el espíritu, pero no véis que él es un yunque, ignoráis la crueldad de su martillo". El error fundamental consiste en no distinguir estos dos tipos de placer: el de dormirse y el de triunfar. Los agotados desean el reposo, la felicidad. Los ricos y los vivos quieren la victoria, la difusión de la sensación de poder en un dominio más vasto. El bueno convierte la norma existencial del hombre-esclavo, del individuo social estandard, en criterio de verdad.

Resumiendo: la sospecha genealógica de que el sentido de los fenómenos está en su origen nos ha permitido desvelar tras la religión el pálpito de una existencia agotada y pobre. El cristianismo es un intento de acondicionar un mundo seguro para un hombre de instintos débiles, para un hombre que vive la experiencia del ser como límite, como sufrimiento y que busca entonces el consuelo en los trasmundos. El valor de todo fenómeno cultural se decide genealógicamente por su referencia a una vida noble o a una vida vil y débil.

\section{6. ¿POR QUÉ EL HOMBRE QUIERE LA RELIGIÓN?}

Estamos ya en condiciones de contestar a la pregunta sobre el origen de la religión. La respuesta es clara: por medio de ella un cierto tipo de hombre se quiere a sí mismo, o, dicho negativamente, el hombre rechaza querer lo que real y fundamentalmente se le escapa. Esta es la razón por la que se trata de una actitud enfermiza: es coherente con una debilidad intrínseca que tiende a no querer ver lo que es, que desea negar lo que le molesta.

Si la religión proviniera de un error de la razón sería fácil de corregir. Pero proviene del miedo, sentimiento no pasajero, nacido del presentimiento de un mundo sin sentido. Se trata de la sabiduría trágica de Sileno. Al rey Midas, que quiere escuchar cuál sería la cosa mejor y más deseable para el hombre, Sileno, después de haber callado durante un largo rato, responde finalmente diciendo: "Estirpe miserable y efimera, hijo del acaso y de la pena, ¿por qué me obligas a decirte lo que, para tí, representa una gran ventaja no escuchar? Lo mejor para tí es del todo inalcanzable: no haber nacido, no ser, ser nada. Ahora, la segunda cosa mejor para tí es morir pronto".

Esta experiencia es muy primitiva. Las antiguas religiones ya concibieron el mundo como una realidad caprichosa dotada de una libertad total respecto del hombre, desnuda de regla y regularidad. Mundo espantoso, poblado de seres arbitrarios, animados de una voluntad incomprensible. El hombre aparece como un ser limitado ante una potencia no domesticada. La religión 
nace del deseo de sobreponerse a esta relación: "la reflexión de los hombres que creen en la magia y el milagro tiende a imponer una ley a la naturaleza: el culto religioso es el resultado de esta reflexión"15. La religión es la organización cultural, moral y dogmática de esta tentativa de apropiación humana de lo desconocido.

El hombre está inclinado a la enfermedad. Si esto no fuera así no sería explicable el éxito de las fantasías religiosas. Ellas necesitan de un tipo de hombre para el que la existencia es entendida bajo la categoría de culpabilidad. La vida es culpable de tratarnos con dureza, del sufrimiento, de la falta de sentido. "Dios creó a los hombres felices, ociosos, inocentes e inmortales: nuestra verdadera vida es una existencia falsa, decaida, pecaminosa, una existencia de castigo... El sufrimiento, la lucha, el trabajo, la muerte, se estiman como objeciones e algo contra lo que se necesitan medicinas" (V.P. $n^{\circ} 224,146$ p.).

Nietzsche investiga lo que en el hombre desea la religión. La sospecha alcanza menos a la propia religión que a lo que en el creyente necesita de ella. Para analizar el fenómeno de la creencia no es útil considerar su contenido racional: en efecto, la variedad de credos y sus contradicciones, sin hablar de los evidentes absurdos que contienen, muestran que el creyente no cree a causa de la racionalidad de la religión. La pregunta es: ¿quién quiere creer en tales absurdos y aberraciones? ¿Por qué es necesario creer contra toda demostración en la incoherencia de los dogmas o en la brutalidad represiva de las morales? La toma en consideración de la voluntad permite entrever que el interés por la creencia viene de su rigor, de su fijeza, de su estabilidad: creer proporciona un punto fijo que permite saber a qué atenerse. Pero ¿quién puede querer la verdad a todo precio sino es una voluntad débil, inconsistente, incapaz o de encontrar en ella misma firmeza o de jugar con la multiplicidad de las interpretaciones?

Espantado por la disparidad no unificable que es él mismo, distendido por las necesidades instintivas pluriformes, el individuo encuentra en la creencia el principio a partir del cual podrá unificar su personalidad. Sea la creencia que sea: damos sentido a la vida en el servicio a un partido, dedicándonos a los pobres o explotados etc. Ellos se transforman en aquello que manda a la voluntad, porque el débil tiene necesidad de inventar una potencia exigente. Por eso proclama su fe en un Dios de justicia, en un proletariado explotado, en la lucha contra la explotación de los pobres etc. El fanatismo es la única fuerza de voluntad a la que pueden ser conducidos los débiles y los inciertos.

15. VALADIER, P. o.c., p. 50. 
La religión así entendida es tan perversa porque es el medio por el cual el débil se afirma a sí mismo por intermedio de la divinidad. Dios se pone al servicio de la criatura enferma, un dios tanto más poderoso cuanto ella es más débil. Por esta invención, se alza el hombre y se proporciona un medio para olvidar su debilidad. "La moralidad de las pequeñas gentes como medida de las cosas: esta es la degeneración más importante que la civilización ha creado hasta ahora, ; $Y$ esta clase de ideal permanece suspendida sobre la humanidad como "dios"!" (V.P., $n^{\circ} 200,134$ p.). ¿Basta con retirar a Dios, a la religión, para no querer ya fijarse a todo precio una certeza que confiera consistencia y justificación a la vida?

El judeocristianismo no encuentra toda su fuerza persuasiva sino porque se dirige a una humanidad ya enferma. Extrae su credibilidad en tanto que ofrece una interpretación gracias a la cual el individuo o los grupos concernidos encuentran sentido a lo que experimentan. El hombre es sufrimiento, pero ¿dónde encontrar sentido al sufrimiento? ¿tiene una causa u origen? ¿responde a un castigo? "Fuera del ideal ascético, el hombre, el animal-hombre, ha estado, hasta el presente, desprovisto de sentido. Su existencia sobre la tierra carecía de finalidad: ¿por qué el hombre? Era una cuestión sin respuesta; la voluntad para el hombre y para la tierra faltaba...” (G.M., $n^{\circ} 28,185$ p.). $\mathrm{Al}$ hombre enfermo la religión ofrece una interpretación cuyo portavoz es $\mathrm{el}$ sacerdote. El hace equivalentes existencia y pecado.

Es el caso de la interpretación sacerdotal de la historia de Israel que es releida como si fuera una consecuencia de la desobediencia del pueblo de la ley de Dios. Esto supone una transformación de todos los valores: leer el mal en la prosperidad, la riqueza y la vitalidad del pueblo, mientras identifica exilio y dispersión con el bien que convertirá al pueblo. El judío Pablo prosigue esta tradición al interpretar la muerte de Jesús como sacrifico por los pecados: falsifica el mensaje de vida y acogida del reino, valoriza el pecado y la muerte. Convierte en presupuesto de la predicación cristiana la idea de que la vida es una prisión. La religión se presenta entonces como liberación. Para ello hay que convencer al hombre de que se sienta oprimido y pecador, así nace la conciencia pecadora. "En todas partes la mirada del pecador, que se mueve siempre en una sola dirección, dirección a la culpa, considerada como causalidad única del sufrimiento; en todas partes la mala conciencia, esa bestia horrible... en todas partes el reinterpretar el sufrimiento como sentimiento de culpa, de temor, de castigo; en todas partes las disciplinas, el cilicio, el cuerpo dejado morir de hambre, la contrición, en todas partes... el grito que pide redención" (G.M. $n^{\circ} 20,164$ p.). El hombre mórbido se da un dios mórbido, un dios humano, pequeño, compasivo, débil, lleno de commiseración. Así Pablo inventa un dios padre que acepta el sacrificio sangrante de su hijo, reservándose para él 
mismo el papel de justiciero. El hombre del rencor tenaz, inapto a la liberalidad, se da un dios que no ama a los hombres sino a condición de que crean en él.

No es la religión la que crea la enfermedad, es el enfermo quien cree encontrar en la religión un sostén y una justificación a su mal. El judeocristianismo llama pecado a la enfermedad humana y así la fortalece. "Dios es el pensamiento que hace contrahecho o torcido a todo lo recto y a todo lo que está quieto, lo hace girar... Pensar esto es torbellino y vértigo para los huesos humanos y vómito para el estómago; en efecto, yo llamo la enfermedad rotante al anhelar tal cosa" (A.H.Z. En las islas afortunadas, 132 p.). Entonces aparece Dios como médico de almas, preocupado por su criatura. Por eso el cristianismo necesita del hombre enfermo y sólo persuade a los que tienen el mundo por feo, injusto, malo. La expansión de la fe en el seno del imperio romano supo explotar la miseria de los esclavos y su humillación por una ciudad orgullosa para convencerlos que la salvación venía primero para ellos. El cristianismo necesita de los que se desesperan. Por ello ha sabido explotar tan bien la hora de la muerte, el espanto que ella suscita: muerte como signo del pecado, de la condenación, muerte como instante decisivo donde se juega la totalidad de una vida, muerte como punto focal de una enseñanza y de una religión organizada alrededor de la idea del dios muerto en la cruz. Se une así la humillación de Dios y la del hombre.

La presunción cristiana consiste en hacer creer al individuo pasajero que tiene un valor eterno y de este modo la humillación va paralela a un orgullo infinito. Todo el designio divino tiene por fin nuestra salvación; cada alma puede considerarse lo bastante importante para que la divinidad haya gastado por ella tesoros de misericordia en su favor. ¿Cómo no sospechar que el débil necesita para subsistir de creer que todo ha sido querido para él, que la eternidad le ha sido prometida? Por ello la predicación cristiana vuelve al hombre interesante. La desmesura del egoismo y del orgullo cristianos, el carácter excesivo de esta religión esta ligado a su naturaleza mórbida: el enfermo no puede querer la justa medida. El quiere lo incondicionado porque no puede aceptar su condición. Religión de la violencia, el cristianismo no tiene el buen gusto del matiz o el pudor de guardar la distancia: necesita de esta hipótesis extrema, un dios único, un redentor que pasa por el sacrificio de la cruz. Necesita de un creyente que se pliegue totalmente a la obediencia de la fe. Suscitado por el orgullo del débil, el cristianismo es excesivo, porque apunta demasiado alto, desnaturaliza lo real y suscita el nihilismo: él ha producido este aborto sublime, el hombre moderno, desilusionado de todo y que, porque se le ha hecho creer en su destino absoluto, descubre ahora su nada y la nada de todas las cosas. 
El círculo se cierra: la presunción cristiana es sospechosa de haber engendrado este nihilismo decadente que Nietzsche encontró en Schopenhauer. La filosofía moderna retranscribe, secularizándolos, los temas cristianos fundamentales, del mismo modo que el pensamiento político contemporáneo. "Los juicios de valor cristianos reaparecen por doquier en los sistemas socialistas y positivistas. Falta una crítica de la moral cristiana" (V.P., n $n^{\circ}$ 5, 32 p.). Comienza con quien se tiene por dominador (dios, la existencia o el devenir, la sociedad injusta o el sistema social), se busca una causa o culpable (el hombre pecador, el no-sentido, los poderosos o el poder), se encierra la totalidad de las cosas bajo un juicio sin remisión (condenación eterna, moral negativista o nihilista, caracter irreformable del sistema social), se hace desesperar al ser humano, privándolo de salvación por sí mismo o ofreciéndole un redentor (cristo, la ascesis, el proletariado o el progreso científico) que se pondrá al servicio de la humanidad caida. Por eso el cristianismo ha dejado su marca sobre el universo convirtiéndolo todo en más feo:"creer malo, es volver malo": carácter productivo y transformador de la creencia: queriendo ver el mundo feo, injusto e insensato, se lo convierte en todo ello. La voluntad se da un mundo a su medida: enfermo y devaluado. "Una resolución peligrosa: la resolución cristiana de considerar el mundo feo y malo lo ha convertido en feo y malo" (G.C. $n^{\circ} 130,165$ p.)

El hombre religioso condena la vida. Es el hombre resentido porque no puede responder a las solicitaciones del mundo exterior. Las impresiones exteriores son acogidas como una sucesión de choques que provocan sufrimiento. Esta vulnerabilidad patológica despierta la necesidad infantil de protección y consuelo. Es el hombre debilitado, inofensivo, humilde y mediocre. Hay toda una pedagogía de la decadencia que identifica moralización y mejora del hombre con su castración. "Esta especie de medicación sacerdotal ha mejorado al hombre: sólo añadir lo que para mí significa mejorado, lo mismo que domesticado, debilitado, postrado, refinado, reblandecido, castrado, es decir, casi lo mismo que dañado, tal sistema pone al enfermo más enfermo, aun suponiendo que lo ponga mejor" (G.M. $n^{\circ} 21,165$ p.). La medicación ascética del sacerdote consiste en romper los instintos, extirpar las pasiones. Se exige al hombre que haga la guerra a su cuerpo. Esta es la cultura de la decadencia.

La verdadera cultura es la antítesis de esta domesticación brutal. La cuestión no es ¿cómo producir el individuo neutro y dócil? sino ¿cómo espiritualizar, embellecer y divinizar un deseo? Para el hombre activo, el enfrentamiento a lo real significa realización de sí gracias a una victoria siempre renovada sobre las fuerzas hostiles del mundo. Una cosa es necesaria: "Que el hombre llegue a estar contento de sí, cualquiera que sea el arte o la ficción de la que se sirve para este fin: sólo entonces adquiere una fisionomía soportable. 
Los que están descontentos de sí mismos están siempre listos a vengarse" (G.C. 290,213p.). El débil se afirma en la voluntad de venganza, única actuación del decadente que quiere así compensar el espectáculo de su debilidad. El fundamento del idealismo metafísico y de la moral es un cierto tipo de voluntad de poder, a saber, la voluntad de venganza como voluntad que se mediatiza a través de negatividades. El débil sólo sabe afirmarse negando.

El análisis genealógico nos ha mostrado las razones por las que el hombre desea la religión y el modo cómo ésta actúa. El cristianismo aprovecha la propia enfermedad humana a la que Nietzsche llama mala conciencia para, envenenándola, hacer de ella una conciencia pecadora. El mal existe, el hombre se resiente de él, pero uno mismo es el culpable de ese mal. El concepto de pecado constituye el centro de la explicación. La moral cristiana se revela como masoquismo y en ello Nietzsche coincide con Freud en su valoración del cristianismo como neurosis obsesiva. La religión refuerza el mal al que se propone como remedio.

\section{EL NIHILISMO}

En los próximos apartados estudiaremos el nihilismo, es decir, cómo la mentira que sustenta la religión se manifiesta como tal mentira. Se trata del desvelamiento del sentido de la fe en Dios como fe en la nada, porque Dios es la máscara de la nada. Y este hecho fundamental en la cultura de occidente es resultado de la búsqueda de la verdad que la propia tradición moral cristiana promueve, por ello podemos hablar de suicidio del cristianismo. Desde entonces el absurdo y el pesimismo acechan a occidente.

El nihilismo es el acontecimiento inaugural de los tiempos modernos. Proclamar el nihilismo es proclamar la muerte de Dios. La muerte de Dios significa que lo suprasensible es rechazado y por tanto también las normas, valores y fines que se encontraban hipostasiados en él. Todos ellos han perdido el derecho a regentar nuestras vidas.

"No hay ninguna verdad, no hay ninguna cualidad absoluta de las cosas, ninguna cosa en sí. Esto es nihilismo, y, verdaderamente nihilismo extremo. Sitúa el valor de las cosas en el hecho de que ninguna realidad corresponde ni correspondió a estos valores, sino que son sólo un síntoma de fuerza por parte del que atribuye el valor, una simplificación para fines vitales"(V.P, $n^{\circ} 13,38 p$.). La muerte de Dios expresa una enorme decepción ontológica: nuestras aspiraciones no apuntan a un absoluto en el que alcanzarían plenitud. El hombre descubre que lo que él tomaba por un diálogo no era sino un monólogo alucinado."Nos hemos templado y endurecido en la comprobación de que las 
cosas del mundo no marchan en absoluto divinamente, ni siquiera en la forma racional, compasiva o justa, según la medida humana: sabemos que el mundo en que vivimos no es ni divino ni moral ni humano, demasiado tiempo lo hemos interpretado de una manera falsa y falaz, mas según el deseo y voluntad de nuestra veneración, vale decir, de acuerdo con una necesidad... la conclusión a que ha llegado nuestra desconfianza es que el mundo no vale tanto como habíamos creido" (G.C. 346, 259 p.) Estamos indefensos ante el sentimiento de absurdidad universal. Un sentimiento que no es natural como pensaba Sartre, resultado de una intuición sobre la contingencia del ser, sino el producto de una cultura. El absurdo no es, por tanto, el objeto de una captación inmediata por parte del hombre, sino la consecuencia de una esperanza decepcionada. No hay absurdo si no hay previamente espera. El absurdo nace de la historia de una decepción respecto al sentido del ser. Nietzsche muestra que en la raíz del sentimiento de absurdo hay un resentimiento inconfesado contra el ser en tanto que éste no se pliega a los cánones morales.

Veamos cómo el mundo-verdad se convierte en una fábula y comprenderemos la génesis del nihilismo. La interpretación metafísica del ser implicaba la percepción de una falta de armonía en el corazón de las cosas, pero hacía posible un acomodo gracias al dualismo entre el mundo sensible y el más allá supra-sensible. Se confería al más allá el valor de un arquetipo sobre el cual ajustar la conducta humana y se conservaba la esperanza de que, por una transformación progresiva de la realidad empírica, el desacuerdo presente sería finalmente superado. Pero el hombre toma conciencia de que este dualismo es un subterfugio destinado a camuflar las contradicciones. Entonces el espíritu descubre el mecanismo de la constitución de los trans-mundos: la proyección. Lo suprasensible está constituido con la ayuda de elementos prestados a la inmanencia sensible. Es el resultado de un "llenado" axiológico: el mundo sensible, condenado, queda situado ante un mundo auténtico. Esta operación implica dos términos: un lugar ontológico que es rellenado y el contenido proyectado en el más allá metafísico. El contenido se elabora sobre la base de lo que valoran aquellos que se designan como buenos, valores procedentes de la voluntad de venganza. La naturaleza de la voluntad de venganza, como voluntad de poder negativa, nos indica cuál es la naturaleza del lugar en el que se cumple la proyección de los valores. Este lugar es la nada misma. No es la nada en el sentido del nihil absolutum de los metafísicos, sino una nada axiológica, relativa al ser. No su opuesto absoluto (tal alteridad es impensable) sino una posibilidad del ser en tanto que el ser pone valores. El nihilismo marca el desvelamiento de esta nada que sostiene el sistema ideal de verdades metafísicas y religiosas y el desvelamiento del proceso por el cual la voluntad de poder negativa ha conseguido confiscar en provecho suyo la tota- 
lidad del mundo real. Es la prueba de la falta de fundamento que constituye los valores reinantes. Descubrimos el valor de los valores como la nada sobre el cual estos valores se apoyan.

El nihilismo representa la muerte de las pretensiones de la decadencia de conservar su dominación sobre el mundo. La decadencia está en el origen de la mentira metafísica, pero ella no conocía todavía esta mentira como mentira. Es decir, ella era en sí el nihilismo, pero no para sí: era un nihilismo inconsciente. La irrupción del nihilismo significa que el nihil de los valores suprasensibles se desvela en la consciencia decadente, obligada a presenciar, impotente, el hundimiento de lo que ella consideraba como su verdad. Explicar la dialéctica que ha conducido a esta situación, es resolver el problema del paso de la decadencia al saber de sí. Las claves de esta dialéctica son:

1. La universalización de la decadencia, resultado de la victoria paradójica de los débiles sobre los fuertes. La decadencia se extiende y convierte en una locura colectiva. Acaba identificándose con la naturaleza humana misma.

2. La manipulación de las categorías lógicas al servicio de la voluntad de venganza y de la fábula metafísica. $\mathrm{El}$ nihilismo ha sido posible porque la voluntad de venganza ha conseguido dominar las categorías desviándolas de su función primera y utilizándolas como material para la elaboración de la fábula. El conocimiento procede de la voluntad de poder por cuanto se esfuerza en encadenar el devenir en las redes de las categorías intelectuales. Así lo intentan los conceptos de finalidad, unidad y ser. Pero separados de esta intencionalidad inmanente, son elevados a la pseudodignidad idealista del sentido en sí, para servir de medida al valor del devenir. El nihilismo, en cambio, descubre el verdadero sentido de las categorías como instrumentos del pragmatismo vital, es decir, como expresión de ciertas perspectivas de utilidad que caracterizan la relación del hombre con la realidad del devenir. El sentido de las categorías reside, no en la aptitud que manifestarían para captar el devenir en tanto que tal, sino en su aptitud para garantizar la dominación del hombre sobre el mundo. Una tal utilidad representa, confrontada al ser del devenir, una simplificación y por ello Nietzsche llama a este conocimiento pragmático un error. El nihilismo es precisamente el desvelamiento de la actividad simplificadora y organizadora (falsificante) del entendimiento al servicio de la voluntad de poder. Descubre que no hay ninguna realidad que corresponda o que haya jamás correspondido a estos valores, sino que son una simplificación útil para la vida. La calumnia metafísica de la vida había nacido de un uso ilegítimo de los conceptos que, de ser expresión del intento humano de dominar la realidad, se habían convertido en expresión de 
un mundo verdadero resistente al devenir. Por eso afirma Nietzsche que seguiremos creyendo en Dios mientras sigamos creyendo en la gramática. El descubrimiento de este hecho nos deja sin transmundos, sin el consuelo del más allá y por ello la tentación nihilista se hace tan fuerte.

3. La moral engendra el ansia de verdad y esta ansia se vuelve contra ella al descubrir el oscuro basamento de sus valores. Entonces la moral se transciende a sí misma. El resultado es un fenómeno ambiguo que se escinde, en el análisis, en dos elementos: el nihilismo (hundimiento de todos los valores metafísicos) y la sublimación de la moral bajo la forma de la pasión del conocimiento, que inaugurando un nuevo modo de filosofar, debe conducirnos más allá del nihilismo.

El nihilismo es el resultado de una veracidad que ha llegado a la edad adulta; nace de lo que viene implicado en la moral. "Pero entre las fuerzas que sustentaba la moral estaba la veracidad: ésta se vuelve finalmente contra la moral, descubre su teología, su consideración interesada; y ahora la comprensión de esa mentira, encarnada hace tiempo y de la cual no esperamos poder desembarazarnos, actúa precisamente como estimulante. Ahora constatamos en nosotros mismos, enraizadas a través de la larga interpretación moral, necesidades que nos parecen como exigencias de lo no verdadero; son estas necesidades a las cuales parece estar unido un valor, las que hacen que soportemos la vida" (V.P., $n^{\circ} 5,34$ p.). El primer aspecto del nihilismo es el de una crisis: se comienza a entrever el contraste entre el mundo que veneramos y el mundo del que tenemos experiencia, el mundo que somos. Una elección nos queda: destruir nuestra veneración o a nosotros mismos. Este último caso es el nihilismo. La amenaza es clara: atascados en esta situación que impone o el sacrificio de la fe o el sacrificio de la vida, el hombre corre el riesgo de abandonarse a la desesperación y, por nostalgia de las ilusiones metafísicas perdidas, preferir el anonadamiento a un nuevo esfuerzo creador. La lucidez no basta. Para salir del impasse, la verdad debe ponerse al servicio de una voluntad heroica, heredera de esta moral. La filosofía de Nietzsche representa el cumplimiento positivo de la superación de la metafísica occidental, el resultado de la inversión de todos los valores nacidos de la metafísica.

Pero hace falta un tercer factor además de la conjunción del nihilismo y del impulso moral sublimado. Este factor es el nacimiento de un nuevo tipo de voluntad de poder que concilia en él la exigencia de la probidad intelectual (resultado de la superación de la moral) y la fuerza de afirmación capaz de reorientar el nihilismo en la dirección de la vida ascendente. Es el objeto de lo que Nietzsche llama la doctrina de la selección. Ella guarda las puertas del futuro. Se trata de crear las condiciones necesarias para la producción de 
un tipo de hombres nuevo, que asociaría en él la espiritualidad y la prodigalidad vital, voluntad de futuro. La espiritualidad es creada por los enfermos, los impotentes, aquellos a quienes la vida rechaza la exteriorización de su voluntad de poder y que son obligados a buscar en ellos mismos su escapatoria, obligados al tormento de la introspección. Pero se constituyen en fermento de una cultura superior, si al superar la tendencia al escepticismo, esta espiritualidad conecta en las almas fuertes con las mayores energías vitales. Nietzsche no predica el regreso de los bárbaros, reclama un tipo de hombre que encarne la reconciliación del espíritu y de la voluntad de potencia afirmativa. "Enseño el no contra todo lo que debilita, contra todo lo que agota. Enseño el sí hacia todo lo que fortalece, acumula fuerzas, justifica el sentimiento de la fuerza. Hasta ahora no se enseñaron ni lo uno ni lo otro" (V.P., $n^{\circ} 54,57$ p.).

Así pues, confrontados al nihilismo, Nietzsche nos sitúa ante la crucial coyuntura histórica que estamos viviendo. Toda la operación de construcción de un transmundo llevada a cabo por los espíritus débiles se manifiesta en lo que tiene de falsedad y cobardía. La vida vuelve a mostrar su peor rostro, su falta de sentido ¿cómo sobrevivir al absurdo?

\section{LA HISTORIA DEL NIHILISMO}

Hay una historia concreta del nihilismo, una historia que debemos contar en detalle si queremos disipar el gran malentendido que empaña la verdad y corre el riesgo de arrastrar la humanidad a la catástrofe. Este camino histórico conduce al hombre siempre más lejos hacia la esencia del nihilismo.

La llegada del nihilismo aporta un obscurecimiento general: el pesimismo. Consiste en el aumento del sentimiento de inseguridad, en la difusión de impresiones de angustia, en una exasperación de las reacciones al dolor. El sufrimiento aparece como la prueba irrefutable de la nulidad de la vida. " $L o$ que se desprende del pesimismo, es la doctrina de la absurdidad de la vida". El nihilismo nos hace pensar: el dolor pertenece a la esencia de la vida; ahora bien, el dolor es un mal; luego la vida es mala. Se asiste así al refluir de la voluntad de afirmación ontológica. El ser parece perder su crédito. Necesitamos, dice Schopenhauer, hacer que cese este escándalo, desgarrar el velo de Maya en el cual una voluntad mala nos retiene cautivos y nos aleja de la beatitud de la nada. "La cuestión de si no ser es mejor que ser, es ya, por sí misma, una enfermedad, un signo de declive, una idiosincrasia. El movimiento nihilista es sólo la expresión de una decadencia fisiológica” (V.P., nº 38,48$)$. Extraer argumentos del dolor para condenar la vida no demuestra nada más que la superficialidad del filósofo que recorre a esta pobre retórica. En cuan- 
to vacila el ideal metafísico, un reflejo de pánico sobreviene y se busca una compensación: el nihilismo incompleto. Se quiere escapar al nihilismo sin transformar los antiguos valores tradicionales, sin tocar su antiguo fundamento en la región ideal de lo suprasensible. Sin duda el nihilismo incompleto reemplaza los valores antiguos por valores nuevos, pero sigue situándolos en el viejo lugar que se reserva como región ideal de lo suprasensible. No se desarraiga el ideal, se seculariza. Dios ha muerto pero sobre su tumba se levanta el hogar de la humanidad futura. El nihilista incompleto es un teólogo sin Dios. El hombre moderno debe cesar en sus vanos esfuerzos de ilusionista.

Todos los expedientes son buenos con tal que ahorren al hombre la percepción del abismo que acaba de abrirse: "La europa de hoy es rica ante todo en excitantes, parece que nada le sea más indispensable que los estimulantes y las aguas-de-vida: por ello esta atmósfera repugnante, apestada, cargada de mentira y de pseudoalcohol que se respira por todas partes" (G.M., $n^{\circ} 26,181$ p.). La humanidad rechaza confesarse que está condenada a reinventar al hombre. En lugar de esto está lista para arrodillarse delante de toda autoridad capaz de prescribirle fines. Esta heteronomía del querer sanciona la persistencia del fetichismo metafísico:

a. Se intenta una especie de solución secular, pero orientada en el mismo sentido, en el sentido del triunfo final de la verdad, de la caridad, de la justicia (socialismo: igualdad de las personas).

b. Se intenta igualmente conservar el ideal moral dando preferencia al altruismo, a la abnegación, a la abdicación del querer.

c. Se intenta descubrir en los hechos una providencia divina análoga a la de otros tiempos, un orden moral que recompensa y castiga.

d. Se intenta incluso conservar un "más allá", sea bajo la forma de una $\mathrm{x}$ irracional de la que se extrae una especie de consuelo metafísico como el de antaño.

La muerte de Dios no marca el fin de la alienación del hombre. Hemos suprimido a Dios, pero se consolida la dimensión de lo divino y se salvaguardia el derecho de proyectar los valores en un absoluto que tiene los caracteres de la antigua transcendencia. La lucha entre los partidarios de la tradición religiosa y los libre-pensadores modernos acaba siendo una querella de palabras. ¿Para qué borrar a Dios del vocabulario, si es para divinizar la materia, la razón o el progreso? Ambos bandos coinciden para fundar el destino de la humanidad sobre la sacralización del ideal. Es el pío fraude del ateismo. 
Primeramente, una declaración de ateismo puede proceder de muchas motivaciones diferentes. Muchos ven en él una manera cómoda de liberarse de las limitaciones que la disciplina religiosa imponía a sus instintos y caprichos. Otros son ateos por indiferencia intelectual o tibieza afectiva. Su negación de la religión es oportunista. Pero sobre todo, el libre-pensamiento se caracteriza por una ceguera voluntaria respecto a las consecuencias de la muerte de Dios. Se rechaza al Dios personal, pero la identificación metafísica del ser y del ideal permanece como dogma intocable.

Persíste la creencia cristiana en la providencia, en la confianza, en la marcha de las cosas, en la fe en el progreso. No hay más que cumplir con el deber para que todo vaya bien. La filiación Kant-Hegel es patente: Kant y su reino de valores morales sustraidos a nuestros ojos pero real; Hegel y su evolución, revelación visible del reino moral que se instaura progresivamente. Por las mismas razones Nietzsche se opone a las dotrinas socialistas, última aparición del idealismo metafísico. No se debe confundir la liberación del hombre con el mito cuantitativo de la felicidad del mayor número posible, y, sobre todo, no se debe cifrar en los deseos del "último hombre".

Además del nihilismo incompleto, se puede hablar de nihilismo pasivo. Este expresa el pleno reconocimiento de la absoluta falta de fundamento de todos los valores, pero en lugar de proceder a la revolución copernicana del querer a la que debería conducir este reconocimiento, se abandona a la delectación morosa de la inanidad universal. El nihilista pasivo mira el mundo con una mirada desencantada, ninguna tarea le parece digna de movilizar sus energías. Es un signo de decadencia y regresión de la fuerza espiritual. Lo bastante escrupuloso para no tolerar ya la mentira del ideal, el nihilista pasivo erige la no-verdad en absoluto: "todo es falso". Incluso recusa toda especie de deseo. Con este nihilismo triunfa la actitud contemplativa del budismo, expresión extrema de la recaida vital que ve al ser deshacerse en el no-ser.

Allí donde subsisten todavía recursos dinámicos, la negación recupera su virtud explosiva y suscita un nihilismo activo. No se trata ya de la creencia de que todo merece perecer, consiste en destruir y por ello implica un cierto grado de fuerza. Se atribuye esta fuerza a los desheredados y a los decadentes. Nietzsche considera el nihilismo bajo dos ángulos. De una parte como coronamiento de la paciente educación por la cual la probidad intelectual ha sido alzada al rango de virtud cardinal: aquí el nihilismo activo testifica la existencia de un espíritu fuerte. Por otra parte, como manifestación de la desesperación de los decadentes. Para ellos el nihilismo activo es un movimiento de decadencia. No se trata de cambiar al hombre y el mundo sino de hacerlos saltar. La rabia de la anihilación oculta el rechazo a adherirse a la voluntad de poder auténtica que es impulso a transcenderse por una actividad creadora. 
Por eso Nietzsche dice: "He aquí mis enemigos: los que quieren subvertirlo todo y no construirse ellos mismos. Dicen: todo esto no tiene valor y rechazan crear valores"

Ahora se trata de extraer del nihilismo las consecuencias últimas, a fin de que se opere la selección humana que permitirá la creación de nuevas tablas de valores. Así la doctrina del eterno retorno se intuye como la expresión del nihilismo más severo, ya que consagra el carácter absoluto de este mundo que el decadente descubre desprovisto de sentido. El eterno retorno constituye el test ontológico decisivo que asegura la demarcación radical del sí y del no, de la voluntad de poder y de la voluntad de la nada. Ahora bien, la doctrina del eterno retorno triunfa sobre el nihilismo desencadenando el pesimismo más mortal, que producirá la selección del elemento más vivo.

Resumiendo: los diferentes tipos de nihilismo muestran como, descubierta la inanidad de los ideales religiosos, éstos se resisten a perecer. Cuesta transmutar los valores que nos han regido durante siglos y por eso el nihilismo se camufla detrás de las creencias políticas, las filosofías pesimistas, las ideas humanistas etc. El reto nietzscheano consiste en crear un tipo de hombre capaz de superar todo pesimismo, afrontar el nihilismo y crear nuevos valores. El hombre debe reabsorber la transcendencia metafísica convertida en poder de creación. El es el nuevo legislador.

\section{LA MUERTE DE DIOS}

Como hemos visto el nihilismo representa esta sacudida de nuestra esencia y de nuestra visión del mundo que Nietzsche piensa como el descubrimiento de la muerte de Dios. No es una fórmula desagradable para un cristiano. En el cristianismo Dios muere para resucitar. La muerte de Dios es transfiguración de la creación. Para Nietzsche se trata de la imposibilidad de seguir siendo cristianos.

¿Por qué ha comenzado a extinguirse el cristianismo? El diagnóstico nietzscheano es claro: el cristianismo sobrevive como moral pero es la moral cristiana la que ha destruido al cristianismo como religión. "El nihilismo radical es el convencimiento de la insostenibilidad de la existencia, cuando se trata de los valores más altos que se reconocen, añadiendo a esto la comprensión de que no tenemos el menor derecho a plantear un más allá o un en-sí de las cosas que sea divino, que sea moral viva. Esta comprensión es una consecuencia de la veracidad altamente desarrollada, y por ello, incluso, una consecuencia de la creencia en la moral" (V.P.. $n^{\circ} 3,33$ p.). El cristianismo es una forma de soportar la vida. Pero el simple rechazo de la vida acaba negándose a sí mismo. Se 
trata de un hundimiento interno. La disciplina sacerdotal ha domesticado al bárbaro. Bajo la presión del ideal ascético se ha operado una educación que produce una inhibición de la vitalidad, pero que agudiza al mismo tiempo el juicio moral. El sacerdote que convence al hombre de su propia culpa es el agente que produce una cultura de la conciencia, un refinamento de su poder de análisis y de crítica. Este es el origen de la curiosidad científica. Por medio de esta educación que dota al individuo de una aptitud cada vez más afinada para juzgar, por la práctica del exámen de conciencia, conduce a interrogarse sobre los fundamentos del dogma: la conciencia crítica se vuelve hacia las afirmaciones de la fe para examinar su validez. La veracidad adquirida descubre que el dogma tiene en contra a la conciencia intelectual y que por fidelidad a la moral no es convincente adherirse a él. Así la supresión del cristianismo es un acto del propio cristianismo: el espíritu de verdad se prohibe la mentira de la fe en Dios. La moral cristiana ha hecho del cristianismo algo no creible. Nietzsche le opone el buen gusto o la decencia: "Lo que ahora se pronuncia en contra del cristianismo es nuestro gusto, ya no nuestros argumentos" (GC, $n^{\circ} 132,165 p$.). No se refuta el cristianismo del mismo modo que no se refuta una enfermedad: sólo la salud refuta. La propia educación cristiana hace imposible adherirse al cristianismo, víctima de sí mismo. La voluntad se interroga y se pregunta para qué quiso creer. $\mathrm{El} \mathrm{hombre} \mathrm{se} \mathrm{vuelve} \mathrm{entonces} \mathrm{al}$ problema del sentido de la vida. La muerte del cristianismo se identifica con esta cuestión, se trata de la inauguración "de un gran espectáculo en cien actos, reservados a los dos próximos siglos de Europa, el más terrible, el más incierto y quizás también el más rico en esperanzas de todos los espectáculos”.

¿Podrá el hombre afrontar la cuestión del sentido? ¿Se refugiará en nuevos ídolos? La eutanasia del cristianismo no resuelve estos problemas; sólo los plantea. Esta es la situación de los europeos: pérdida de suelo firme, riesgo de hundimiento en la aventura. La muerte de Dios al hacer imposible la fe, abre las cárceles que son las convicciones, pero sólo si el miedo a los riesgos de la libertad no obliga a encerrarse en nuevas cárceles. Hace falta un trabajo lento para que la muerte de Dios no aparezca sólo bajo el aspecto de una pérdida (nihilismo reactivo), sino como la posibilidad del gran sí a la realidad restituida en toda su inmensa profundidad. Nos sentimos angustiados porque naufraga todo lo que el mundo había poseido hasta ahora como lo más sagrado y poderoso. El problema es si seremos capaces de adherirnos al nuevo infinito. "Ved qué plenitud hay entorno a nosotros. Y es bello mirar, desde la sobreabundancia, hacia mares lejanos; pero ahora yo os ha enseñado a decir: superhombre. Dios es una suposición; pero yo quiero que vuestro suponer no vaya más lejos que vuestra voluntad creadora. ¿Podríais vosotros crear un Dios? ¡Pues entonces no me habléis de dioses! ¡Mas el superhombre sí podríais crear- 
lo!" (A.H.Z.,En las islas afortunadas, 131 p.). Por primera vez el hombre tiene que orientarse en el mar, ante un horizonte que se aleja. Mientras los símbolos cristianos proceden de relaciones jurídicas (juez-culpable), penales (carcelero-prisionero), médicas (médico-enfermero) o de vigilancia (pastor-ganado), implicando todas ellas relaciones de dependencia y de coacción, los símbolos nietzscheanos apuntan a una no relación, a la apertura y al infinito, como el mar. Comienza una era en la que la tierra se ha desprendido de todo sol. Ya no es posible encerrar la existencia en un solo tipo de interpretación.

Cuando Dios es identificado con un límite insoportable para una voluntad creadora, Nietzsche remite a la voluntad, no a un obstáculo externo que bastaría suprimir para encontrar su pleno desarrollo. La voluntad que necesita de Dios no es una voluntad creadora, es la voluntad que recibe las verdades del cielo, frente a la voluntad que se emancipa de toda heteronomía: "Habla y balbucea así: este es mi bien, esto es lo que yo amo, así me agrada del todo, únicamente así quiero yo el bien. No lo quiero como ley de un Dios, no lo quiero como precepto y forzosidad de los hombres: no sea para mi una guía hacia supertierras y hacia paraisos" (A.H.Z. De las alegrias y de las pasiones, 63p.). Dios emana de una voluntad que no puede aceptar el ser del mundo. Esta es justamente la enfermedad de la que Nietzsche quiere curar el hombre: la tendencia a hacerse centro y rechazar lo que no es él. La voluntad de poder auténticamente afirmada no es la que olvida la realidad, encerrándose en un universo a la medida del hombre, sino la que bendice el sol superabundante de la realidad que el hombre no es. Esta es una de las más importantes consecuencias de la muerte de Dios, la de remitirnos a nuestra existencia real, más acá de todas las interpretaciones que la desvalorizan. El sin fin de la existencia libera de las pseudo-concepciones totalizantes del mundo y de las pretensiones a atribuirse una interpretación decisiva del universo. Las cosas no se reducen a la opinión que se tenga de ellas. Muertos los ideales es necesario multiplicar las miradas, ver con ojos diversos y de modo multiforme lo que es multiforme. Se supera así la megalomanía humana. El monótono teismo no conduce al hombre más que a su propia imagen proyectada sobre la esencia de las cosas. Un hombre sano se deja fecundar, y éste es el papel maternal de todos los creadores de obras: su creación procede de una voluntad que se ha dejado informar y que, consciente de la relatividad de su inserción, está dispuesto a incorporar la ilusión al acto creador. La verdadera inocencia está hecha de indiferencia, de aptitud para dejar las cosas a su libre movimiento y para criticar la voluntad de asimilarlas demasiado deprisa a sí mismo. El engaño del intelecto está en no aceptar su limitación. La posición nietzscheana debe delimitarse por dos actitudes: la del hombre teórico (Sócrates) que mide las cosas por su poder para comprenderlas y que se coloca por encima de la 
existencia para juzgarla y la representada por Jesús que, a la inversa, enseña una praxis y un sí incondicional. Para un hombre que no persigue ya la satisfacción febril de sí, porque se posee a sí mismo, la pasión de la verdad no es proyección o búsqueda de sí, sino deseo de lo que es tal como es, y no para colmar un deseo. La proyección de sí mismo sobre las cosas proviene de una voluntad inquieta que intenta imponer la tiranía del entendimiento y, por tanto, anexionarse la realidad que es fondo sin fondo, abismo, secreto impenetrable: como el mar, el horizonte o el sol. El ser es ininterpretable, ha de ser sólo escuchado. La muerte de Dios impone una tarea: ¿qué puede ser el hombre después del cristianismo?

Lo dionisíaco es la respuesta al cristianismo. El hombre dionisíaco es el gran afirmador de la vida hasta en sus abismos más terribles. Dioniso representa lo que el cristianismo ha rechazado. No busca un sentido a la vida: el mundo está más allá de toda justificación, mundo caótico, semejante a un mar agitado por fuerzas eternamente cambiantes y, sin embargo, siempre idénticas a sí mismas. En contra del crucificado paulino que exalta la muerte contra la vida, Dioniso afronta la muerte con la certeza de la sobreabundancia de la vida y de su poder recreador. El sufrimiento es interno a la santidad de la vida. El sí a la vida sólo es posible para el niño porque él es inocencia (no condenación y denuncia de la realidad como culpable) y olvido (no resentimiento). Pero no se es niño espontáneamente. Así Jesús: si es necesario distinguirlo de esta realidad histórica que es el cristianismo reactivo, sigue valiendo que Jesús ha entrevisto la posición justa, la que hace justicia a lo real sin juzgarlo. Aconsejó la acogida, el decir sí al reino, a una presencia paternal; si esta acogida es lo único que vale, nada vale en comparación: religión, estado, familia, riqueza... Niño, pero niño ingenuo que descubre en la cruz que el sí auténtico implica el no, que la belleza del reino implica, como su contraste, el horror del sufrimiento y la muerte. Su alegre mensaje no es un gay saber: saber que sabe lo real en sus contrastes espantosos, pero que encuentra la serenidad del reir, no el reir sarcástico atemorizado, sino el reir liberador ante una realidad que posee en ella misma su poder justificador. "Si mi virtud es la virtud de un bailarín, y a menudo ha saltado con ambos pies hacia un éxtasis de oro y esmeralda: si mi maldad es una maldad riente, que habita entre colinas de rosas y setos de lirios: dentro de la risa se congrega todo lo malvado, pero santificado y absuelto por su propia bienaventuranza" (A.H.Z. Los siete sellos, 317 p.). El niño del Gay saber no tiene menos voluntad que el león: tiene más y de otra manera. La condición es la voluntad de poder que sabe decir sí a lo que la transciende. Ella reconoce que lo que es, está más allá de todo juicio posible, más allá del bien y del mal. Inocencia que significa que este pobre ser pasajero que es el hombre no puede acusar sin ridículo a la realidad. Ella es no-sen- 
tido y el individuo encuentra salvación en afirmarla como tal. Quizá no hay más salvación que en reconocer que no la hay.

La muerte de Dios crea una situación completamente nueva. Nuestra modernidad está hecha a la vez de la herencia cristiana que conduce al nihilismo y de posibilidades trágicas abiertas por el redescubrimiento de la realidad sin orilla, sin tierra firme, de nuevo infinita. Como hemos visto en este apartado Nietzsche propone la creación de un hombre dionisíaco, fuerte, amante de la vida tal como ella es.

\section{EL SACERDOTE}

Si el cristianismo ha marcado decisivamente la cultura occidental, su figura principal es el sacerdote, correa de transmisión de los ideales ascéticos. Nietzsche cree que es necesario el estudio de este personaje si queremos entender lo que ha sucedido, comprender quiénes somos, por qué sentimos y pensamos tal como lo hacemos.

El es el gran educador de occidente no el filósofo. La filosofía siempre es segunda respecto a la influencia religiosa y la educación moral. El sacerdote es portavoz del ideal ascético. El asceta quiere vivir pero lo hace negando lo que le contraria. Posee una voluntad débil que sólo negando puede afirmarse. Este ideal encuentra eco porque la vida del hombre se experimenta como sufrimiento, por eso hay una complicidad estructural entre el hombre y el mensaje del sacerdote. El ejercicio de su ministerio se hace a través de dos poderes: el del médico y el del teólogo.

a. El sacerdote médico: el hombre vive su vida como sufrimiento sin comprender por qué. El enfermo no puede encontrar remedio sino junto a otro enfermo pero que sea capaz de dar razón del mal. Hace falta un débil que sea señor y éste es el sacerdote. La interpretación sacerdotal habla de pecado y culpa como causa del dolor. "Trae consigo ungüentos y bálsamos, no hay duda; mas para ser médico tiene necesidad de herir antes; entiende este encantador $y$ domador de animales rapaces, a cuyo alrededor todo lo sano se vuelve enfermo" (G.M., $n^{\circ} 15,147$ p.). El sacerdote cambia la dirección del resentimiento producido por el sufrimiento en la vida débil: la causa del mal es identificada con el mismo que sufre, sufrimos por nuestra propia culpa, porque somos pecadores. La herida se agranda porque el responsable es uno mismo. "De esta manera se aprovechan los peores instintos de todos los que sufren con la finalidad de lograr la autodisciplina, la autovigilancia, la autosuperación" (G.M. Ibid.). Todo ello introduce la moral en occidente como medio terapeú- 
tico para curar la enfermedad y como conducta recta por la que el enfermo piensa que se somete a la divinidad y se hace perdonar.

b. El sacerdote teólogo: el papel médico no se da sin una función de explicación y de convicción. La medicina sacerdotal consiste en una interpretación teológica de la existencia. El enfermo debe buscar explicación a su mal. Así nace la voluntad de verdad a cualquier precio que se plasma en la creencia. Todas las fantasías relativas al más allá sacan su fuerza de la voluntad de aferrarse a sí mismo, de asentir a un mundo confortable y erradicar el espanto.

$\mathrm{El}$ sacerdote concibe su papel como el de quien recuerda el orden moral de las cosas y en su nombre exige sumisión. Su poder consiste en su capacidad de interpretar la existencia según la divinidad. Todo ello testimonia una debilidad para existir y el intento de darse a sí mismo un medio reconfortante de llevar la vida reduciéndola a interpretación. El cristianismo es un epifenómeno, lo que actúa detrás es la necesidad de salvación. El sacerdote no se limita a mantener esta necesidad. La explota de acuerdo con la forma conjugada de la medicina que aviva la necesidad y de la teología que fija la verdad y subordina la salvación a su afirmación. Bajo la influencia sacerdotal es la realidad divina la que se pretende ordenar a la salvación del hombre al mismo tiempo que se quiere conocer la conducta moral que satisface sus exigencias. El sacerdote es identificado en Nietzsche con el ideal ascético mismo.

La crítica nietzscheana del sacerdote ascético se dirige a todo tipo de mediadores, y la del ideal ascético, a toda actitud que se viva por mandato o por sustitución o en orden a otra cosa que ella misma. Es sacerdote el que consuela y da sentido al sufrimiento del débil; el que aporta un apoyo gracias al cual la vida puede ser vivida. Es sacerdote el que ordena al individuo y le posibilita comprenderse: príncipe, clase social, médico, dogma, conciencia de partido. Es sacerdote el que hace causa común con el débil, se identifica con él, el que tiene necesidad de elevar su compromiso político, sindical, científico al rango de una identificación con la justicia, el bien o la verdad. Es sacerdote el que hace tomar conciencia al débil de su enfermedad, de su explotación, el que hiere para poder aportar el remedio. Es sacerdote el que tiene necesidad de la miseria de los hombres para poder aportar su interpretación e impulsar así su dominación. El sacerdote cura sacando de quicio, acusando globalmente. Hoy las nuevas mediaciones sacerdotales son más veladas pero no menos reales que antaño. En definitiva, el estudio del sacerdote nos permite certificar un espíritu de rechazo de la vida por miedo a lo terrible, concretado en la necesidad de salvación.

El importantísimo papel del sacerdote en la formación del hombre europeo queda en evidencia cuando analizamos el tema de la mala conciencia tal 
como Nietzsche lo plantea. La mala conciencia representa el punto de partida de la hominización, es decir de la llegada del espíritu al mundo. Nace de la represión de los instintos y de la concentración de todas las facultades bajo la jurisdicción exclusiva del aparato intelectual. El hombre, en adelante impedido para descargar al exterior sus pulsiones vitales, se ve obligado a apoyarse sobre su sola conciencia para asegurarse el control de las pulsiones y la adaptación al medio. Esta interiorización da lugar a una hipertrofia del aparato reflexivo y a una ruptura brutal entre el yo y sus energías vitales elementales. Lo que es naturaleza es golpeado por la culpa y así el hombre se convierte en su propio verdugo. "Todos los instintos que no se desahogan hacia afuera se vuelven hacia dentro, esto es lo que yo llamo la interiorización del hombre: únicamente con esto se desarrolla en él lo que más tarde se denomina su alma. Todo el mundo interior, originariamente delgado, como encerrado entre dos pieles, fue separándose y creciendo, fue adquiriendo profundidad, anchura, altura, en la medida en que el desahogo del hombre hacia fuera fue quedando inhibido... La enemistad, la crueldad, el placer en la persecución, en la agresión, en el cambio, en la destrucción, todo esto vuelto contra el poseedor de tales instintos: ése es el origen de la mala conciencia" (G.M., $n^{\circ} 16,96$ p.). El espíritu representa autodominio, control sobre la animalidad. Si esto es así, tenemos que reconocer que el despertar del espíritu y el despertar del sentimiento de falta están rigurosamente ligados. La subjetividad humana adquiere su profundidad gracias a un proceso de interiorización que implica la negación de la inocencia animal. El espíritu es negatividad que surge como conciencia de sí culpable, como conciencia infeliz, como mala conciencia: "Se había introducido la dolencia más grande, la más siniestra, una dolencia de la que la humanidad no se ha curado hasta hoy, el sufrimiento del hombre por el hombre, por sí mismo: resultado de una separación violenta de su pasado de animal..." (G.M., $n^{\circ} 16,97$ p.).

Más profundamente diremos que la mala conciencia refleja exactamente la ley ontológica de la voluntad de poder. Esta no consiste en la posesión estática de una potencia, sino que es dinámica creadora que se cumple en la información de una materia ("La relación más elevada es la del creador y la de la materia que él trabaja"). Esta estructura ontológica encuentra su figura simbólica en la diada Apolo-Dionisos. Apolo domina y atempera a Dionisos en la medida en que Apolo simboliza el esplendor armonioso de la forma y Dionisos, la exuberancia caótica de las energías vitales que sirven de materia a la información apolínea. La voluntad de poder nos aparece como un Janus bifronte que nos ofrece de un lado el rostro de Apolo y de otro el de Dioniso. Dioniso es la fuerza en su hybris original y Apolo el grado de razón que la fuerza se incorpora en favor de la transcendencia. La forma es la espirituali- 
zación de la fuerza, la belleza, la gracia del poder. Dionisos no representa sólo los instintos en su brutalidad anárquica, sino la esencia íntima de la voluntad de poder en tanto que inquietud radical, creadora, pasión demiúrgica. La voluntad de poder existe como violencia dionisíaca natural que se sublima constantemente en la forma apolínea: "El devenir, sentido e interpretado desde dentro, sería la creación continua de un ser intranquilo desbordante de rique$z a$, infinitamente empujado adelante, de un dios que no triunfaría del tormento de la existencia más que a fuerza de metamorfosis y de perpetuo cambio" 16 Querer, para Nietzsche, es transcenderse y transcenderse es crear formas: " $E l$ querer hace libres: pues querer es crear, y sólo para crear debéis aprender", dice Zaratustra. (Cfr. A.H.Z. De las tablas viejas y nuevas, 285 p.). La transcendencia es la esencia de la voluntad de poder, acto de informar una materia. $L a$ mala conciencia refleja una interiorización de este proceso. El hombre se escinde en materia y forma. La materia sobre la que se ejerce el dominio y la información es el hombre mismo. Ya no acontece como en estadios anteriores, el dominio simple de unos hombres sobre otros, sino el dominio del hombre sobre sí mismo. Los dominadores imponen a los dominados la represión de sus instintos. La vida se pone en contradicción consigo misma. El yo animal se convierte en materia prima que debe esculpirse y transcenderse. La oposición materia-forma deviene conflicto intrapsíquico en el interior de una misma individualidad orgánica en donde luchan espíritu y vida. El espíritu aparece entonces como enfermedad de la vida, negatividad interiorizada que perturba la vida natural: "En el fondo es la misma fuerza activa que hemos visto operando de una manera grandiosa en los artistas de la violencia, en los organizadores para crear estados, la fuerza que, ahora empequeñezida y mezquina, crea la mala conciencia, obrando en el interior de una manera retrógrada, en el laberinto del corazón, para hablar con Goethe, construyendo ideales negativos, es precisamente este instinto de libertad (que yo llamo, en mi lenguaje, la voluntad de poder)" (G.M., $n^{\circ} 18,99$ p.).

Así pues la mala conciencia arranca al hombre de la bestialidad primitiva e instaura el fenómeno del espíritu. Pero en un segundo momento entra en escena el sacerdote ascético y éste contamina el sentimiento de malestar con el de pecado. La mala conciencia se convierte en algo diferente y peor, en conciencia pecadora. Ahora contaminada por la idea de pecado ya no debe ser referida al desdoblamiento en materia y forma tal como sucede en el proceso de interiorización de la voluntad de poder que no puede expresarse hacia fuera pero que sigue realizando su trabajo de escisión hacia dentro. En la conciencia pecadora el propio individuo es puesto como culpable del dolor:

16. GRENIER,J, J. o.c. p. 432 Cita "La voluntad de poder". 
entonces el resentimiento se vuelve contra uno mismo. De este modo la enfermedad se convierte en definición misma del hombre: "La tierra tiene una piel, y esta piel tiene enfermedades. Una de ellas, por ejemplo, se llama hombre" (A.H.Z. De los grandes acontecimientos, 193 p.). El hombre pecador concibe la vida como castigo por su pecado y la somete a la voluntad de Dios para poder expiarlo. El dolor y el sufrimientos son merecidos y debe soportarlos esperando la recompensa del más allá. Este hombre recorre la vida enfermo esperando su fin, cargado bajo un fardo de deberes y obligaciones, como el camello de Zaratustra. "Yo sufro: alguien tiene que ser culpable de esto, así piensa toda oveja enferma. Pero su pastor, el sacerdote ascético, le dice: está bien, oveja mia, alguien tiene que ser culpable de esto: pero tú misma eres ese alguien, tú misma eres la única culpable de tí... Esto es bastante audaz, bastante falso: pero con ello se ha conseguido al menos una cosa, con ello la dirección del resentimiento queda cambiada" (GM, $n^{\circ} 15,149$ p.). Se entiende la negatividad inherente al espíritu como sufrimiento debido al pecado, no como resultado de la represión de los instintos (la mala conciencia es peligrosa porque puede ser atrapada por la religión pero es también la condición del progreso: sin la existencia de un interior el hombre no saldría de la naturalidad brutal de los primitivos).

Sólo hay dos posibilidades: o la mala conciencia se deja captar por la vida ascendente y la unión del espíritu y el vigor vital engendran la pasión por el conocimiento que arroja al espíritu libre en la aventura de la verdad, o la mala conciencia se encierra en su malestar y se muda en voluntad de venganza contra la vida. En el primer caso el espíritu, aun a costa de la espontaneidad vital, permite el dominio de la naturaleza y el progreso. Normalmente un fenómeno de ósmosis social debería permitir, según Nietzsche, corregir los excesos de la mala conciencia provocando corrrelativamente la hominización de los bárbaros que dominan y la renaturalización de los esclavos humanizados por la larga construcción de la interioridad. Este fenómeno llevaría a cabo la reconciliación del espíritu y la vida. Pero el curso de la historia no ha seguido esta progresión bien contrabalanceada. Es el segundo de los casos. La culpabilidad ligada a la mala conciencia es contaminada por la moralización religiosa de la noción de deuda y crea una horrible perversión de la esencia genérica del hombre: la mala conciencia se transforma en conciencia pecadora. "El advenimiento del Dios cristiano, que es el Dios máximo a que hasta ahora se ha llegado, ha hecho, por esto, manifestarse también en la tierra el maximun del sentimiento de culpa. Suponiendo que entre tanto hayamos iniciado el movimiento inverso, sería lícito deducir, con no pequeña probabilidad, de la incontenible decadencia de la fe en el Dios cristiano, que ya ahora se da una considerable decadencia de la consciencia humana de culpa: la completa victoria del ateis- 
mo pudiera liberar a la humanidad del sentimiento de hallarse en deuda con su causa prima. El ateismo y una especie de segunda inocencia se hallan ligados" (G.M., $n^{\circ} 20,104$ p.).

Para restituir a la voluntad de poder su rectitud ontológica, la transformación del idealismo se intuye como imprescindible. Esta voluntad debe recuperarse como afirmación de la vida, transcendencia creadora, artista pero fiel a la inmanencia. Voluntad de poder que desarraiga permanentemente al hombre de su medio humanizado, más allá de las ficciones que nos creamos para dominar el devenir, pero que no debe impulsar una huida, una ascensión vertical hacia lo divino. Transcender el mundo significa ir más allá de la bella apariencia de las formas y aventurarse hasta el abismo de la verdad, más allá de las verdades útiles y aseguradoras. El criterio absoluto de poder es la aptitud de la voluntad para soportar la amenaza de la ilimitación que está implicada en la veracidad: "La medida de la suprema fuerza: en que medida un hombre puede vivir sobre hipótesis, y no sobre creencias, es decir, aventurarse en mares ilimitados"17. La inhibición de los instintos y el retorno de la crueldad vital contra la vida misma, crean las condiciones necesarias al despliegue de la transcendencia más trágica. Porque el espíritu es la voluntad de poder trabajando por superarse, transcendiendo la pura vida hacia el abismo de la verdad, cruel y duro.

Hemos abordado en este apartado uno de los aspectos claves de la crítica nietzscheana al cristianismo, una de las razones por las cuales el buen gusto prohibe la creencia religiosa. Ella ha convertido la mala conciencia, necesaria para la sublimación y mejora del hombre, en conciencia pecaminosa, es decir, en conciencia masoquista que explica el sufrimiento de la vida como castigo por la propia culpa. Con ello la vida es anihilada bajo el concepto de culpa. Vivir es pagar y expiar un pecado original. Esta es la tara que arrastra occidente y el sacerdote ha sido su inductor.

\section{EL ABISMO DE LA VERDAD O LA RECUPERACIÓN DEL DEVE- NIR}

El conocimiento está siempre situado y por eso no puede alumbrar un saber exhaustivo sobre el ser sino sólo proveer interpretaciones que el propio conocimiento se ve impulsado a sobrepasar. Conocimiento parcial pero, en cuanto voluntad de poder, esfuerzo constante por arrancarse a esa parcialidad y transcender la perspectiva del pragmatismo vital para desvelar el ser según

17. GRENIER,J, J. o.c., p. 448 Cita “Obras Póstumas”. 
el espíritu de justicia. Así la noción de voluntad de poder engloba dos temas antagonistas:

a. El pragmatismo vital: hace del conocimiento una operación demiúrgica guiada por el interés;

b. La probidad filológica: consagra la aptitud del querer para sobrepasar todo límite y organizar el proyecto del conocimiento según la norma de la justicia.

La voluntad de poder une en la unidad indisoluble de un mismo impulso creador, el acto de informar una materia, de poner en ella el sentido que refleja la espontaneidad demiúrgica del querer y el acto de transcender toda posición finita, toda significación sedimentada. Habrá un momento del despliegue de la voluntad de poder que coincidirá con la libre producción de interpretaciones fijas, investidas de una función reguladora, a este momento lo llamamos el pragmatismo vital. Pero dado que la voluntad de poder es empuje para transcenderse sin cesar, la voluntad de conocer no puede detenerse en un sistema de interpretaciones. Toda forma tiene por destino ser abolida en nombre de este mismo poder del que ella fue una encarnación efímera. Puesto que la voluntad de poder es transcendencia, la forma no es más que transición, camino, paso. Así esta voluntad engloba a la vez la determinación de la interpretación como donación imperialista de sentido y como filología irreprochable. La primera corresponde al pragmatismo vital, que manifiesta la energía plástica del querer, la segunda a la pasión del conocimiento que manifiesta el heroismo de una transcendencia fiel a la justicia.

El pragmatismo vital nos muestra el conocimiento como instinto de apropiación y conquista. En cuanto nacido de la voluntad de poder es imperio. Así Nietzsche lleva a sus últimas consecuencias la idea kantiana según la cual el conocimiento es esencialmente una actividad sintética constituyente. Esta esencia poético-práctica del conocer es una forma de dominación. Nietzsche ve en las categorías simples instrumentos que sirven para organizar lo real según las necesidades del hombre. La falta del idealismo metafísico es fabricar un mundo suprasensible enteramente ficticio hipostasiando las categorías como si fueran determinaciones ontológicas (en esto va más allá de Kant y sigue a Hegel): la voluntad de poder las requiere para subyugar el devenir. "Todos los valores con los cuales hemos tratado hasta ahora de hacernos apreciable el mundo y lo hemos desvalorizado después al haberse mostrado inaplicables; todos estos valores son los resultados de determinadas perspectivas de utilidad, establecidas para conservar la imagen de dominio humano, pero proyectadas falsamente en la esencia de las cosas" (V.P., $n^{\circ} 12,37$ p.). 
El conocimiento así entendido es creencia, es decir, imposición de un sentido previamente establecido, objetivación de un deseo en una forma de manera que haga más fácil la vida. La creencia introduce un compromiso existencial. Significa que toda especie de juicio implica la adhesión apasionada del sujeto que conoce al contenido de su conocimiento. De este modo producimos las condiciones de posibilidad para nuestra supervivencia. En Nietzsche el juicio se confunde con la creencia porque no hay un entendimiento independiente de la voluntad, de mis necesidades más imperiosas. El juicio de conocimiento traduce la exigencia propiamente biológica de moldear el mundo en función de la perspectiva que me ha sido asignada en cuanto individualidad finita. Conocer es creer porque lo que conozco tiene por fin serme útil. Este fenómeno traduce las urgencias vitales más tiránicas procedentes de la sabiduría del cuerpo. Hay una asimilación del mundo al yo orgánico que ya comienza a realizar la imaginación, matriz de las palabras y los conceptos.

La determinación del conocer como creencia conlleva la reducción de la verdad a valor. Este término indica que se ha producido una ruptura de la indiferencia o de la igualdad entre las cosas y utilizamos el verbo valer para significar que la conciencia no puede mirar un objeto sin ratificarlo. Conocer es informar e informar es "conformar a". El principio de razón se encuentra reducido por Nietzsche al principio de validez. El conocimiento tiene su fundamento en la normatividad de la vida, por ello no nos proporciona datos neutros sino síntesis de ser y de deber ser. Vivir es apreciar. La unidad de medida es el conjunto de valores que para cada tipo de voluntad de poder favorecen la expasión vital. La verdad no es por tanto una entidad lógica, sino el producto de una praxis, el signo de una victoria conseguida por la voluntad de poder en su esfuerzo por plegar el mundo a sus normas.

Es importante subrayar que para Nietzsche la verdad en tanto reducida al valor-útil se designa como error. El acto de conocer como expresión del instinto de dominación no consigue el desvelamiento del ser en su verdad propia, se limita a organizar el devenir según las necesidades de los diversos centros de fuerza. La verdad es una especie de error, a falta del cual un cierto tipo de seres vivientes no podrían vivir. "La vida no es un argumento porque el error podría encontrarse entre las condiciones de la vida". Calificar esta verdad de error, nos impide confundir esta verdad-útil con el tipo de verdad que traduce un modo de relación con el ser radicalmente otro, el que designaremos como pasión del conocimiento y comó filología rigurosa.

La metafísica y la religión hispotasían el valor-útil como esencia del ser. De ello resulta la identificación entre ser y bien y la eliminación de todas las determinaciones negativas, de la que hemos hablado más arriba. La moralización del ser conlleva automáticamente la diabolización de lo negativo. El 
ser es abordado bajo el único prisma del valor. Así la religión aparece como una patología del pragmatismo vital, como una hipertrofia de la necesidad de seguridad, signo de una degeneración del querer que no puede soportar la dureza de la vida. El hombre religioso se instala en el universo familiar de sus ficciones. En él el pragmatismo ya no está al servicio de la voluntad de vivir, sino de la voluntad de la nada. Confiscado por la decadencia, se convierte en expresión de la moral de los esclavos. Nietzsche cree su deber restaurar la significación auténtica del pragmatismo vital. La utilidad práctica de la creencia no puede determinar los sentidos de la verdad ontológica, de lo contrario conduce directamente al idealismo y a la religión. La verdad útil debe abdicar de sus pretensiones de fijar el estatus de la verdad originaria. De lo contrario la religión sería verdadera porque engendraría consecuencias prácticas de acuerdo con lo que pide el bien. Pero cuando Nietzsche habla de utilidad para la vida, no hay que olvidar que fija el sentido de esta noción por referencia a la distinción de la vida ascendente y la vida decadente. Sólo la verdad que está al servicio de la vida ascendente merece ser calificada de útil. Lo que es útil a los decadentes es nocivo a la vida ascendente.

El criterio de verdad reside en la intensificación del sentimiento de poder. El poder auténtico designa el aumento de la dominación que un individuo consigue ganar sobre el mundo, pero bajo reserva que esta dominación se ejerce en provecho de la vida ascendente. El poder mide entonces la aptitud de la voluntad para crear formas apolineas que exalten el deseo de transcenderse. Se trata del pragmatismo verdadero que no degenera en idealismo utilitarista. El pragmatismo expresa aquí el momento de la transcendencia que consiste en el acto de informar una materia. A este momento corresponde el error-útil.

Pero el valor no se confunde con la verdad incluso aunque estimule las energías demiúrgicas de la vida. Una idea no es verdadera porque nos confiere el máximo de poder. Al contrario, revela con ello que es simplemente un medio de falsificar inteligentemente lo real. Pero la esencia de la voluntad de poder no se agota en la actividad de asimilar lo real organizándolo como mundo. El otro momento de la transcendencia coincide con la ilimitación de la transcendencia. La esencia de la voluntad de poder engloba a la vez el acto de crear valores (valores-útiles) y el acto de transcenderlos, ya que es impulso a ir siempre "más allá de". Si se considera la voluntad de poder no ya en su función demiúrgica sino en su aptitud para transcender al infinito conservando la disponibilidad absoluta que permite a las cosas desvelarse como tales, todos los valores son objeto de sospecha. El problema es entonces el grado de verdad al cual un ser puede alzarse sin romperse como consecuencia de este esfuerzo: "La dosis de verdad que un hombre soporta sin degenerar, esta es su 
medida" El poder no designa ya la extensión del imperio de la voluntad de poder, sino el coraje trágico frente a la verdad. El valor se convierte en ser fuerte. El verdadero poder de la voluntad de poder reside en la aptitud para transcenderse hacia la verdad, porque la verdad encarna la amenaza suprema. Requiere del hombre la mayor bravura y abnegación, porque es la prueba más temible. Por eso nos tenemos que engañar.

La justicia para con las cosas, más allá del idealismo metafísico y del pragmatismo legítimo de la vida ascendente, nos libera de todas las proyecciones antropomórficas y nos obliga a considerar como determinaciones fundamentales del ser aspectos que el idealismo se obstinaba en excluir de su definición: el pluralismo y el devenir. Si examinamos, a la luz de la justicia, la estructura ontológica del error útil, es decir si nos preguntamos qué relaciones establece la voluntad con el ser como realidad fluyente y pluridimensional, descubrimos que la creencia, manifestación del dinamismo conquistador de la voluntad de poder, es un proceso de asimilación que opera por simplificación y por solidificación de lo real. La creencia niega todos los caracteres del ser que dificultarían la asimilación. Como actividad simplificadora, borra el pluralismo, elimina el equívoco, la diferencia, la contradicción, con el fin de suscitar la ilusión de que el ser concuerda con nuestras exigencias de especie. Como actividad de sustantificación del devenir, se aplica a enmascarar la fluidez, niega el cambio, la génesis, la muerte, es decir, transpone el devenir en ser substancial y permanente disimulando así la entropía que afecta a todo lo real. La creencia representa la mayor injusticia que pueda concebirse respecto del ser, es la antítesis de la veracidad filológica. La voluntad de verdad como voluntad de dominar la naturaleza es una gigantesca empresa de falsificación. A esta empresa colabora decididamente la religión pero también sus sustitutos modernos como la ciencia y la tecnología.

$\mathrm{Si}$ el principio de la injusticia reside en la voluntad de reprimir el devenir disimulándolo tras el decorado de un mundo construido bajo el modo del ser substancial, el principio de la justicia consiste en dejar al devenir desvelarse en persona, por eliminación de todo lo que podría solidificarlo. Es el adversario de la creencia, y traduce la resolución de dejar al ser mostrarse en su verdad última. Esta verdad se opone tanto al error-útil del pragmatismo vital como al error-nocivo de la religión. Implica la afirmación de la inocencia del devenir, librándolo de todos los reproches que nos dicta la voluntad de venganza. Se corren grandes riesgos cuando se expone a la humanidad a la justicia. Esta situación conlleva una conversión trágica que arranca al hombre de su medio y lo convierte en un aventurero del conocimiento, un ser sin patria, abocado a la duda. "El error es una cobardia... Toda conquista del conocimiento resulta del coraje, de la dureza para consigo, de la limpieza hacia sí 
mismo". Es importante saber si el hombre puede sobrevivir al desarraigo que le impone el proyecto de la veracidad absoluta. Descubriremos que la ilusión y la mentira son inherentes a la vida misma y que una probidad intelectual irreprochable la perjudica. Debemos aceptar que nuestra relación con el ser sólo puede ser oblicua.

En el momento en que tomamos conciencia de la incompatibilidad que existe entre la expansión de la vida y el servicio leal de la verdad, se revela el sentido último de la verdad originaria. Esta verdad es el abismo de la muerte. Querer incondicionalmente lo verdadero, es querer morir. La pasión del conocimiento es thánatos, instinto de muerte: "El conocimiento es para la humanidad un magnífico medio de anihilación" Esto no desacredita el ideal de la filología rigurosa, establece sólo que no debemos erigir la justicia y la veracidad en normas absolutas. Afirma la necesidad de una autolimitación de la voluntad de conocimiento. El refugio frente a la verdad es la apariencia. Si el fondo del ser es un abismo, la sabiduría suprema consiste en permanecer firmemente en la superficie. Esta apariencia protectora Nietzsche la asimila al arte. El es la santificación de la ilusión y de la mentira, el único espacio en el que la vida puede fructificar sin ser fulminada por el rayo de la verdad. Si no tuvieramos el recurso de replegarnos en los oasis de nuestras ficciones antropomórficas, habríamos perecido hace ya tiempo en los desiertos que el instinto de conocer nos empuja a explorar. El arte no es diversión que alivia la pena de existir, sino productividad. Hay arte allá donde asistimos a la modelación de una materia. Coincide con la actividad plástica de la voluntad de poder, actividad que caracterizada en términos de conocimiento corresponde al pragmatismo vital. Ya que lo real es el devenir, la falsificación pragmatista del devenir es el fenómeno estético fundamental. La asimilación de lo real se realiza al precio de disimular el ser. Si exaltamos nuestros poderes demiúrgicos, debemos glorificar no la verdad sino la mentira. La metafísica, la moral, la religión, la ciencia son considerados como diversas formas de la mentira, necesitamos de su ayuda para creer en la vida. Necesitamos que la vida nos inspire confianza. Cuando por un esfuerzo de transcendencia, la voluntad de poder consigue extraer del caos un orden armonioso, experimentamos alegría. Esta alegría sanciona toda victoria de la voluntad de poder sobre lo que se le resiste. El reflejo objetivo de esta alegría en el obra misma, es la belleza. La belleza es el testimonio gravado en el ser, de la aptitud de la vida para transcenderse sin cesar. Ella nos convence para perseverar en nuestro ser. El arte es el gran estímulo para vivir.

La apología del arte nos hace comprender que el momento del pragmatismo vital no es un instante accidental que tendría por destino abolirse en el despliegue de la transcendencia, sino un momento primordial, investido de 
una dignidad al menos equivalente a la que posee el proyecto de desvelar el ser según la justicia. "Tenemos el arte afin de no morir por causa de la verdad". La mentira del arte es distinta de la mentira idealista y religiosa dado que favorece la vida ascendente, mientra que la religión tiene por finalidad apuntalar la fe en un más allá que condena la vida del más acá. En la religión, la proyección de valores se pierde en una nada metafísica. Pero la buena ilusión es fidelidad a la tierra, acuerdo de la voluntad de poder con las condiciones concretas de su expansión. Al menos la mentira artística envuelve una cierta conciencia de sí como mentira y por ello una comprensión tácita de la verdad originaria, lo que no sucede con la religión, calumnia idealista del más acá sensible. Frente a ésta se necesita un equilibrio entre la ilusión y el saber. Este equilibrio es la esencia de la cultura trágica, equilibrio entre el momento estético del pragmatismo vital y el momento de la veracidad filológica. Esto sólo es posible para los más fuertes no necesitados de creencias extremas, que aman el absurdo, el azar. En ellos se expresa la doble vocación de la voluntad de poder como informadora de lo real (asimilación, imperialismo vital, mentira del arte) y desveladora de lo real (justicia, probidad filológica, verdad originaria). El ser nos obliga, simultáneamente, a violentar lo real para colmar las aspiraciones de la vida y a hacerle justicia para mantener los derechos de la verdad originaria. El hombre debe conciliar estos dos imperativos antitéticos y hacer penetrar en la vida que es negación de lo verdadero, una verdad que es muerte, negación de la vida. La desmesura conducirá al nihilismo: tanto por el exceso del pragmatismo vital (su degeneración en el hombre débil conduce a la religión) o por hipertrofia de la veracidad (nihilismo pesimista de Schopenhauer). Es el ser mismo el que promueve la solidaridad del error y la verdad. "No, estamos hartos de este mal gusto, esta voluntad de verdad, de verdad a toda costa, esta locura de adolescente en el amor a la verdad: para eso somos demasiado serios,demasiados alegres, demasiados astutos, demasiado profundos... Ya no creemos que la verdad continúa siendo verdad si se le arranca el velo" (G.C., $n^{\circ} 4,35$ p.). La vida es lo que, en el ser, es participable al hombre, mientras que la verdad es lo que se substrae a la participación, porque no se puede vivir con la verdad. El ser se hace vida para que los diferentes existentes puedan ser, y él mantiene su transcendencia haciéndose amenaza para la vida. Como consecuencia el ser nos destina a habitar en lo no-verdadero y, querer la ilusión, es pronunciar el juramento solemne que nos une a la vida. La voluntad de poder que consiente en limitar su impulso de conocer para no inflingir la ley dictada por el ser, testifica en ello que ha apostado por el ser contra la nada. "Se debería respetar más el pudor con que la naturalera se ha ocultado tras enigmas e incertidumbres variopintas. ¿Quizá 
sea la verdad una mujer que tiene sus razones para no dejar ver sus razones" (G.C:: Ibid.).

El ser es plenamente afirmable. Basta que se haya vaciado con ardor la copa de un solo instante, que se haya aceptado la belleza de un solo gozo, para que esta única afirmación conlleve el retorno de la totalidad de los sucesos y de los seres. "Suponiendo que dijéramos que sí en un determinado momento, nos encontramos con que habremos dicho no sólo sí a nosotros mismos, sino a toda la existencia, porque nada existe por sí mismo ni en nosotros ni en las cosas, y aunque sólo una vez haya vibrado y resonado nuestra alma, como una cuerda en función de la felicidad, sería necesaria toda la eternidad para reconstruir las condiciones de este único momento, en que decimos sí" (V.P, n $n^{\circ} 1025$, 358 p.). La afirmación es por esencia totalizante porque el todo está necesariamente incluido en cada afirmación particular. No es la afirmación del asno, animal paciente y dócil, que acepta cargar con el fardo de lo real y que dice sí porque no sabe decir no. Su aceptación es una aceptación servil, el asno se limita a soportar lo real tal como es en lugar de amarlo con un amor creador que no duda en negar, en rechazar y destruir. Afirmar el ser no es arrodillarse ante lo real adorándolo como la figura de la necesidad. El hombre que dice el verdadero sí, carga con lo real transformándolo, sabiendo querer lo que hay: "Ah, amigos míos, cuando os metáis enteros en vuestro obrar, como la madre se mete toda entera en su hijo, diré entonces que ésta es vuestra definición de la virtud" (A.H.Z., De los virtuosos, 146). Cada hombre prueba su virtud sobreponiéndose al azar, obligando a los más humildes acontecimientos de su vida a rodearse en una forma superior que manifieste la legalidad propia de su voluntad: "Yo soy Zaratustra el ateo: yo me cuezo en mi puchero cualquier azar. Y sólo cuando está allí completamente cocido, le doy la bienvenida, como alimento mio. $Y$ en verdad, más de un azar llegó hasta mí con aire señorial: pero más señorialmente aún le habló mi voluntad, y entonces se puso de rodillas imporando, implorando para encontrar en mí un asilo y un corazón y diciendo insinuante: Mira Zaratustra, cómo sólo el amigo viene al amigo" (A.H.Z. De la virtud empequeñecedora, 241 p.). La densidad ontológica de mi existencia es exactamente proporcional al cantidad de coraje, de lucidez, de amor, de nobleza que soy capaz de invertir en cada uno de mis actos.

Queda así aclarado el sentido último que la realidad tiene para Nietzsche y el papel que el cristianismo juega. La verdad es abismal y el engaño es necesario pero con tal que no perdamos de vista que es un engaño. En este sentido sólo el arte, juego con las apariencias, nos permite sobrevivir. Pero el cristianismo es el engaño que no sabe que es engaño. Sucede así porque esta mentira nace en el espíritu débil que no podría soportar saber que al creer en un más allá se confunde. En el cristianismo la mentira debe pasar 
simplemente por verdad, tal es la necesidad pavorosa de seguridad que lo anima, tal la debilidad que lo alienta. El es el pragmatismo-útil llevado al exceso, confundido con la verdad radical. El es nihilismo camuflado, odio, cansancio de vivir.

\section{CONCLUSIÓN CRÍTICA}

1. La discordancia entre el yo y el mundo ha llevado al ser humano a plantearse el problema del más allá. Con él se expresa la esperanza de una reconciliación. En el mundo la posibilidad de cumplimiento está ligada a lo que los griegos llamaban el kairós, la ocasión favorable. Pero esta ocasión es el privilegio del azar. Frecuentemente la realidad inflige dolores, decepciones y frustraciones. El yo se descubre abocado a lo accidental, a la fuerza ciega que arruina al sentido y se mofa de los valores. Esta fuerza ciega es el mundo mismo. Existir es estar expuesto a la anulación. La decepción es más brutal y la revuelta más vehemente al descubrir que entregado a la muerte, la interpretación amable de la vida es una pura quimera.

2. Tal como Freud explica, la vida obliga al yo a adaptar el principio de placer al principio de realidad si quiere ser eficaz en sus objetivos. Y esta educación en el sometimiento a las constricciones de lo real es el proyecto de conocer la verdad. Pero la verdad está al servicio de la vida, esta es la advertencia de Nietzsche. Antes que ideologías sociales, los productos de la cultura son ideologías vitales. Por eso intentar el conocimiento de la verdad más allá de su posible utilidad vital es ya el resultado de una sublimación. Y esta verdad, de acuerdo con Nietzsche, consiste en que no hay nada más allá de lo que el mundo nos muestra. Lo transreal es sólo una estructura antropológica, una exigencia del yo en el seno de su desacuerdo con lo real. El problema, a mi modo de ver, consiste en investigar si hay experiencias o fenómenos privilegiados que aún siendo frágiles, alusivos, tenues, constituyan el índice de una transcendencia que se pone como respuesta a la exigencia yoica. Entonces sería posible unir lo transreal y el impulso hacia la transcendencia que Nietzsche remite a un proyecto humano estrictamente horizontal, desplegado al interior del devenir del ser.

3. Nietzsche utiliza como concepto clave, en su interpretación de lo transreal, el de proyección. Sería el resultado de la exigencia de transcendencia que domina al yo. Nietzsche se ve en la obligación de dar cuenta de ella transfiriéndola a uno de los polos de la realidad inmanente. Así la ilimitación del 
deseo se satisface en el concepto de poder. Todo ser se sobrepasa en la búsqueda de un mayor poderío. Este sobrepasamiento se expresa en conceptos como Dionisos, superhombre, eterno retorno, voluntad de poder... que están en contraste con la experiencia cotidiana del mundo. Aquella que, como Sócrates, Nietzsche critica en su concepto del último hombre, el hombre vulgar, el yo sonámbulo. Así cree encontrar en la inmanencia misma la respuesta al deseo del yo y salvarlo de su exilio en el mundo inmanente tal como éste se nos presenta en su inmediatez. Pero este desdoblamiento de la realidad en dos polos del que uno sería la respuesta a lo que el yo exige ¿es una salida tan distinta de la que Nietzsche critica? ¿que otra cosa es el eterno retorno si no un concepto fantasma para expresar ese anhelo de transcendencia que ahora debe satisfacerse en lo inmanente? ¿no se reconoce con ello la insatisfacción del yo en su instalación en lo real? Las exigencias del yo no aciertan a conceder realidad a lo transreal, pero tampoco a los conceptos que desde la inmanencia quieren ser también una respuesta. Creo que no sólo Nietzsche no consigue lo que quiere sino que su filosofía no hace sino evidenciar ese descontento consustancial a la vida en su desacuerdo con lo que hay.

4. ¿Puede un ente ser afirmado como existente aunque se sustraiga a la experiencia sensible? Lo transreal no puede convertirse en Dios por una operación de la cual el hombre tendría la iniciativa y el control. La exigencia del yo delimita un cierto campo para la manifestación divina, pero el sentido último de los conceptos de bondad, infinitud,transcendencia... no sabría ser claramente fijado a menos que pudiéramos apoyarnos sobre indicios reales, en los que reconoceríamos los signos de una revelación divina. Estamos dispuestos por las exigencias del yo a escuchar la verdad de Dios, pero debe ser él el que se haga oir. Sólo indicios reales pueden dar contenido a la anticipación comprensiva que existe en el hombre de lo infinito.

5. La existencia de Dios debe establecerse contra la duda existencial y la sospecha valorativa. Contra la duda existencial tenemos los testimonios transcendentales. Son signos que comunican un significado, un indicio que señala hacia algo más allá de lo fenoménico. Se trata de todas aquellas experiencias que apuntan hacia la afirmación de Dios, porque ellas son ya experiencias de Dios, presentidas por la estructura del deseo humano. Desde ellas la fe se valida a sí misma. Contra la sospecha valorativa hay que mostrar que la afirmación de Dios no degrada el mundo inmanente. Nietzsche nos empuja a reconocer el entusiasmo y la admiración que la experiencia de la riqueza de la vida nos produce, al mismo tiempo que la desesperación por la miseria universal y la angustia por la necesidad de elegir entre opciones siempre ambi- 
guas. Ninguno de estos datos, que forman parte de una fenomenología de la vida humana, deben ser desconocidos.

6. Frente a la sospecha valorativa creo que debe profundizarse en la idea de Dios como aquél que no ha de venir a nosotros revelándose desde "fuera" porque ya está desde siempre en comunión íntima con nuestro ser. Esto significa que Dios no posee más intereses que los de nuestro propio desenvolvimiento. El dualismo heredado de la tradición griega debe ser negado de manera absoluta.

\title{
BIBLIOGRAFÍA CONSULTADA
}

\section{OBRAS DE NIETZSCHE}

NiETZSCHE, F. La voluntad de poderío, Biblioteca Edaf, Madrid 1990.

NiETzSCHE, F. La genealogía de la moral, Alianza Editoral, Madrid 1995.

NiETzSCHE, F. Así habló Zaratustra, Alianza Editorial, Madrid 1978.

NIETZSCHE, F.Más Allá del bien y del mal, Alianza Editorial, Madrid 1986.

NIETZSCHE, F. La gaya ciencia, Ed. Akal, Barcelona 1988.

NiETZSCHE, F. Humano demasiado humano, Edaf, Madrid 1988.

\section{OBRAS SOBRE NIETZSCHE}

DELEUZE, G. Nietzsche y la filosofia, Anagrama, Barcelona 1994.

Deleuze, G. Nietzsche, Presses Universitaires de France, Paris 1995.

FInK, E. La filosofia de Nietzsche, Alianza Editorial, Madrid 1982.

GrANIER, J. Nietzsche, Presses Universitaires de France, Paris 1994.

Granier, J. Le problème de la vérité dans la philosophie de Nietzsche, Ed. du Seuil, Paris 1991.

SAVATER, F. Idea de Nietzsche, Ariel, Barcelona 1995.

VALADIER, P. Nietzsche l'athée de rigueur, Desclée de Brouer, 1975.

VALADIER, P. Nietzsche y la crítica del cristianismo, Ed. Cristiandad, Madrid 1982.

VatTimo, G. Introducción a Nietzsche, Ed. Península, Barcelona 1987.

\author{
P. MASA BAZÁN \\ Estudio Teológico Agustiniano \\ Valladolid
}

